\title{
THE \\ AMERICAN SUPREME COURT AS AN INTERNATIONAL TRIBUNAL
}

\author{
BY
}

HERBERT A. SMITH 


\section{Digitized by the Internet Archive in 2008 with funding from Microsoft Corporation}





\section{const. S649}

\section{THE}

\section{American Supreme Court}

AS AN

\section{International Tribunal}

BY

\section{HERBERT A. SMITH, M.A.}

Of the Inner Temple, Barrister-at-Law; Professor of Jurisprudence and Common Law, McGill University, Montreal; formerly

Fellow of Magdalen College, Oxford

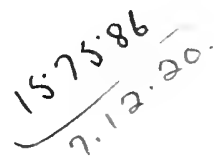

\section{NEW YORK OXFORD UNIVERSITY PRESS}


Copyright 1920 BY THE

OXFORD UNIVERSITY PRESS

American Branch

PRINTED IN U. S. A. 


\section{PREFACE}

Whatever form the League of Nations may ultimately take it must contain some provisions for the settlement by judicial means of justiciable disputes between members of the League. For about a century and a quarter the Supreme Court of the United States has been entrusted under the Federal Constitution with the decision of such controversies between the States of the American Union. Since it has worked under peculiar conditions and within a very restricted area the student will see that inferences drawn from its history can only be applied with considerable qualification to any Court of the Nations that may hereafter be set up. Nevertheless this is the only permanent court, as distinguished from occasional arbitration commissions, which has. hitherto attempted in any degree to discharge the functions of a true international tribunal, and it is therefore clearly desirable that the nature of its work should be as widely as possible studied at the present time.

This essay aims at giving in a small compass a reasoned summary of all the inter-State cases hitherto decided in the Supreme Court. As I am not writing primarily for lawyers or other technical students I have so far as possible avoided all technicalities. Questions of procedure, for example, are almost entirely ignored, and I have also passed lightly over many matters which, although important in themselves, are of interest mainly to students of American constitutional law. The Supreme Court has been keenly conscious of its functions as an international tribunal, and it is this aspect of its work which I wish to emphasize. I have no desire to 
write propaganda either for or against the League of Nations, and it is. possible that different minds may draw different conclusions from a study of the history of the Supreme Court. To my mind the experiment appears within its own limits as a great success, but I have no wish to slur over the difficulties which the Court has encountered or to minimize the differences between the conditions of a North American Union and those of a League embracing most of the civilized nations of the world.

In a work of this kind it would be merely pedantic to cite numerous authorities. For the convenience of lawyers I have given references to the decisions in the original Supreme Court reports, which are to be found in most of the principal law libraries. Dr. James Brown Scott has collected all the inter-State cases into two volumes published in New York by the Oxford University Press under the title of Judicial Settlement of Controversies between States of the American Union, and in a third volume has made a valuable analysis of these cases in chronological order. This exhaustive work has been the principal source-book for my essay, as it must be for any other student who wishes to study the history of the Supreme Court as an international tribunal.

To Dr. Scott personally I am indebted for valuable advice and encouragement in the preparation of this little book, the substance of which was delivered in the form of lectures at Oxford in the summer term of I9I9. A word of the warmest gratitude is also due to many generous hosts in Washington, New York, and the Southern States, whose kindness to a wandering British officer in I9I 8 did more than any books could have done to quicken my interest in American institutions.

H. A. S. 


\section{CONTENTS}

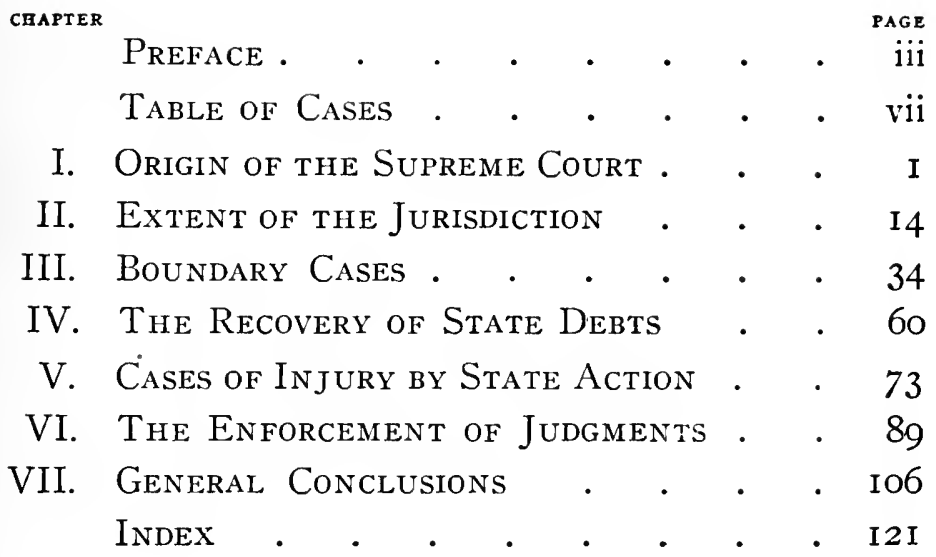





\section{TABLE OF CASES}

Ableman v. Booth (I858); 2I Howard, 506... Alabanna v. Georgia (I859); 23 Howard, 505.. Arkansas v. Tennessec (I9I8); 246 U. S., I58. Cherokee Nation v. Georgia (I83I) ; 5 Peters, I Chisholm v. Georgia (I793); 2 Dallas, 419.... Collector v. Day (I870); I I Wallace, I I $3 . . . .$. Cuba v. North Carolina (I9I7); 242 U. S., 665. Dred Scott Case; see Scott v. Sandford.

Florida v. Georgia ( I850); i I Howard, 293..... Florida v. Georgia ( I854); 17 Howard, $478 . .$. . Hepburn v. Griswold (I870); 8 Wallace, 603... Indiana v. Kentucky (1890); I 36 U. S., 479.... Indiana v. United States (1893) ; I 48 U. S., I48 lowa v. Illinois (1893); I47 U. S., I ........... Kansas v. Colorado (I902); I 85 U. S., I $25 \ldots$ Kansas v. Colorado (1907) ; 206 U. S., 46...... Kansas v. United States (I907) ; 204 U. S., 33I Kentucky v. Dennison, Governor of Ohio (I860) ; 24 Howard, 66............... Legal Tender Cases (I87i) ; I2 Wallace, 457... Louisiana v. Mississippi (1906); 202 U. S., I

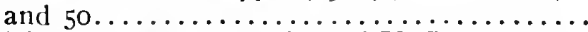

Louisiana v. Teras (I900); I76 U. S., I....... $M c C$ ulloch v. Maryland (1819) ; 4 Wheaton, 316 Maryland v. West Virginia (I9I0) ; 2I7 U. S., I and $577 \ldots \ldots \ldots \ldots \ldots \ldots \ldots \ldots \ldots \ldots \ldots$

Minnesota v. Hitchicock (I902); I85 U. S., $387 \ldots$ Missouri v. Illinois (I90I); I80 U. S., 208..... Missouri v. Illinois (1906); 200 U. S., $496 \ldots .$. Missouri v. Illinois (I906); 202 U. S., $598 \ldots$. Missouri v. Iowa (1849); 7 Howard, 660...... Missouri v. Iowa (1897): I65 U. S., I I8........ Missouri v. Kansas (1908); $2 \mathrm{I} 3$ U. S., $78 \ldots \ldots$. Missouri v. Kentucky (I870); I I Wall., 395.... Missouri v. Nebraska (1904); 196 U. S., 23.... Nebraska v. Iowa (I892); I43 U. S., 359..... Nebraska v. Iowa (1892); I45 U. S., $519 \ldots . .$. New Hampshire v. Louisiana ( 1883 ); $108 \mathrm{U} . \ddot{\mathrm{S}}$.,

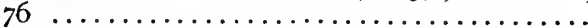

New Jersey v. New York ( I830); 3 Peters, 461 New Jersey v. New York (1831); 5 Peters, 284 New York v. Connecticut (I799); 4 Dallas, I.. New York v. Louisiana ( 1883 ); 108 U. S., $76 .$. PAGES

$37-8,55$ $55-6$ I $5,73-5,87,89$

$9,60,94$ 66

$3,18,32,37$

I I

$40-\mathrm{I}$

$64-5$

$42-3$

$3,24-5,8 \mathrm{I}, 84$ 33,8 I $-8,97$, I I I

I 8-I9, 95-7

II, II 3

$26,47-52$

$22-4,77-9,87,97$

66,90

53-5

$3 \mathrm{I}$

$25-6,79$

$79-8 \mathrm{I}, 88,97$

I7, $36-7$

36

53

$39-40$

47

$4 \mathrm{I}-2$

42

2I

I4

15

I4

$2 \mathbf{I}$

North Carolina v. Tennessee (I9I4); 235

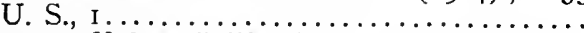

"Paquete Habana," The (I900); i Pennsylvania v. Wheeling $\mathcal{E}$ Belmont Bridge Co. $(1856)$; I8 Howard, $421 . . . . . . . . . . .$. 
Rhode Island v. Massachusetts ( 1833 ) ; 7 Peters,

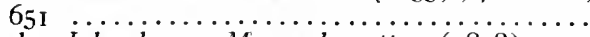

Rhode Island v. Massachusetts ( 1838$) ;$ i2

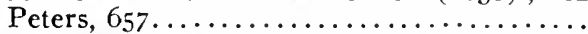

Rhode Island v. Massachusetts ( 1846$) ; 4$ How-

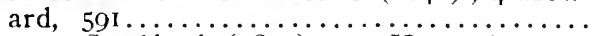

Scott v. Sandford (i857); is Howard, 393... I I, 9I-3, I I 2-3, I I

South Carolina v. Georgia ( 1876$)$; 93 U. S., 4 .

South Carolina v. United Statcs (1905); 199 U. S., $437 \ldots \ldots \ldots \ldots \ldots \ldots \ldots \ldots \ldots$

South Dakota v. North Carolina (igo4); 192 U. S., $286 \ldots \ldots \ldots \ldots \ldots \ldots \ldots \ldots \ldots$

United States v. Louisiana ( 1887 ) i 23 U. S., 32

United States v. Louisiana (1888); I27 U. S., 182

United States v. Michigan (igo3);

United States v. New York (1896); I60 U. S.,

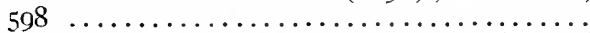

United States v. North Carolina (i8go); 136 U. S., 2I I . . . . . .................

United States v. Texas ( 1892 ); I43 U. S., $62 \mathrm{I}$.

United States v. Texas (I 896$)$; I62 U. S., I....

United States v. Wong Kin Ark (1898); 169 U. S., $654 \ldots \ldots \ldots \ldots \ldots \ldots \ldots \ldots \ldots$

Virginia v. Tennessee (1893); i48 U. S., $503 \ldots$

Virginia v. Tennessec (1903); 190 U. S.. 64...

Virginia v. West Virginia ( I870); I I Wallace,

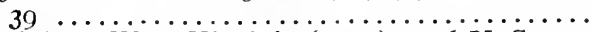

Virginia v. West Virginia (1907); 206 U. S., 290

Virginia v. West Virginia (I908);209 U. S., 5I4 Virginia v. West Virginia (I9I I);220 U. S., I Virginia v. West Virginia (I9I I) ; 222 U. S., I7 Virginia v. West Virginia ( I9I3) ; 23I U. S., 89 Virginia v. West Virginia (1914);234 U. S., I I 7 Virginia v. West Virginia (I0I5); 238 U. S., 202 Virginia v. West Virginia (1916); 241 U. S., 53I Virginia v. West Virginia (1918);246 U. S., 565 Washington v. Oregon (I908); 2 I I U. S., I27.. Washington v. Oregon (Ig09); 214 U. S., $205 \ldots$ Worcester v. Georgia (1832); 6 Peters, $515 \ldots$

I9-2I, 35, 38-9;

$27-8,67-72$

68-9, 107 


\section{ORIGIN OF THE SUPREME COURT}

In order to appreciate the part which the Supreme Court has played in the history of the United States it is necessary to understand clearly the political theory upon which the whole Constitution rests. This theory, shortly stated, is that the United States is a voluntary union of sovereign and independent States. Thus the "Articles of Confederation and Perpetual Union," ratified in $178 \mathrm{I}$, declared that "each State retains its sovereignty, freedom, and independence, and every power, jurisdiction, and right which is not by this Confederation expressly delegated to the United States in Congress assembled." So again in the existing Constitution it is declared by the Tenth Amendment, which was ratified in I79I, that " the powers not delegated to the United States by the Constitution, nor prohibited by it to the States, are reserved to the States respectively or to the people." In other words the Federal Government in all its organs is theoretically only an agent enjoying such limited powers as have been delcrated to it by the joint authority of the sovereign and independent States.

Looked at historically this doctrine rests upon a considerable straining of the facts. The several States have never actually been independent in the sense in which, for example, France and Spain are independent powers. Before the Revolution they were united by their common dependence upon the British Crown. During the war, which lasted from $I 775$ to $I 783$, they were no less united by the necessity of common military action. While the
P. 4345
A. 
war was still in progress they effected a formal union by the "Articles of Confederation," the ratifications of which were completed in I78I. In I789 this union, which had proved too loose to be workable in practice, was superseded by the "Constitution of the United States," under which the country has been governed to this day. In the course of time the number of the States has increased from thirteen to forty-eight. The great majority of these new States have been created by Federal legislation out of Federal territory, and have never enjoyed even a transient independence. A few have been acquired by cession from foreign powers, and subsequently erected into States. Texas alone has known a fleeting independence in the brief interval between her separation from Mexico in 1836 and her incorporation into the United States in 1845.

But the political importance of the doctrine is in no way affected by the weakness of its historical foundation. It was deliberately adopted as and still remains the governing principle of the whole Union. To British readers it has a special interest, because it was consciously taken in 1900 as the foundation for the Constitution of the Australian Commonwealth, the framers of which preferred to follow the Federal principle of the United States rather than the unitary theory which governs the Constitution of the Dominion of Canada. ${ }^{1}$ For our present purpose the importance of the doctrine lies in the fact that it has compelled the Supreme Court in deciding controversies between the States to assume the rôle of an international tribunal. An English Court, deciding a case between two county councils, will treat the parties exactly as if they were two ordinary corporations. But the American Supreme Court is compelled to adopt a

1 South Africa, on the other hand, has aciopted the unitary principle. 
different attitude when the parties before its bar are States of the Union. Speaking of the application of the English procedure to such cases Chief Justice Taney said in the case of Florida v. Georgia in $1854:^{1}$

"These precedents could not govern a case where a sovereign State was a party defendant. Nor could the proceedings of the English Chancery Court, in a controversy about boundaries, between proprietary governments in this country, where the territory was subject to the authority of the English Government, and the person of the proprietary subject to the authority of its courts, be adopted as a guide where sovereign States were litigating a question of boundary in a court of the United States. They furnished analogies, but nothing more."

So again Chief Justice Fuller, delivering judgment in the case of Kansas v. Colorado in $1902,{ }^{2}$ said:

"Sitting, as it were, as an international, as well as a domestic tribunal, we apply Federal law, State law, and international law, as the exigencies of the particular case may demand."

Bearing this fundamental principle in mind, let us consider the steps which led up to the establishment of the Supreme Court.

The Declaration of Independence was published at Philadelphia on the 4 th July, I776. In the next year the delegates of thirteen States assembled in the same city drew up the "Articles of Confederation and Perpetual Union," which were an attempt to form a Federal union with the minimum surrender of State rights. The first article of this document gave the new commonwealth the name which it has ever since retained. The second laid down the fundamental principle of State sovereignty in

117 Howard, 492.

2185 U. S., 146. 
the words which have been already quoted. In the third article the object of the Confederation is described in the following words :

"The said States hereby severally enter into a firm league of friendship with each other, for their common defence, the security of their liberties, and their mutual and general welfare, binding themselves to assist each other against all force offered to, or attacks made upon them, or any of them, on account of religion, sovereignty, trade, or any other pretence whatever."

This is not the place to describe in detail the administrative and legislative arrangements of the Confederation. Suffice it to say that they were designed to give only a bare minimum of power to the central government, and to reserve as much as possible to the individual States. A small Congress was established, in which each State was to have one vote. Diplomacy was forbidden to the States, but their right was recognised to make war individually in cases of emergency. Military forces were to be raised and equipped by the States, though placed under the control of Congress for the actual operations of war. States were allowed to regulate their own customs duties, so long as these did not violate any treaty obligations undertaken by Congress. In short, the Confederation was, as Lord Bryce says, " rather a league than a national government."

The provisions for the settlement of inter-State disputes are contained in the ninth Article, and begin as follows :

"The United States, in Congress assembled, shall also be the last resort of appeal, in all disputes and differences now subsisting, or that hereafter may arise between two or more States concerning boundary, jurisdiction, or any other cause whatever." 
The Article, which is too long to be quoted in full, goes on to provide that, when any dispute comes before Congress, it shall be referred to a body of commissioners selected in a certain way from a large panel; " and the judgment and sentence of the Court, to be appointed in the manner before prescribed, shall be final and conclusive."

Upon this it will be observed that the Confederation makes no provision for a Federal judiciary or for any permanent tribunal superior to the State Courts. Disputes between States are to be referred to a body of commissioners appointed separately to deal with each case as it arises. The procedure suggests an arbitration rather than a lawsuit, and is in some respects a foreshadowing of the rules adopted by the Hague Conference in 1907 for the settlement of international disputes. Nothing is said about enforcing obedience to the decision.

The scheme of union thus devised was from every point of view a complete failure. Its weakness became apparent as soon as the bond of a common military necessity was dissolved in 1783 . The central government was far too feeble to control the conflicting interests of the several States, and became an object of general contempt. Treaties with foreign powers were not observed, while irresponsible legislation and violent disorders soon proved the incompetence of the States for separate self-government. Washington described the situation as no better than anarchy, and the new commonwealth naturally failed to command any respect in the eyes of other nations.

It was evident that such a state of things could not last. Either disruption or closer union was bound to come, and in 1786 delegates from five States met at Annapolis in Maryland to discuss possible reforms. In the next year, acting on their recommendation, a full 
Convention, from which Rhode Island was the only absentee, met at Philadelphia and gave America the Constitution under which she has lived ever since.

The debates in the Convention ranged over a wide field, and disclosed the division, which was to last so long in American politics, between the advocates of a strong central government and the champions of State rights. But a spirit of reasonableness was in the air, men of all parties being deeply impressed with the grave danger of the existing situation. In particular they realised that the Union, as it stood then, would be almost helpless against external aggression.

For the present we are concerned only with the question of judicature. The first proposals for a national judiciary were contained in the "Virginian Plan" propounded on the 29th May, I787, by Edmund Randolph of Virginia, afterwards Attorney-General of the United States. After consideration by a committee a draft scheme was reported to the Convention, in which it was recommended "that the jurisdiction of the national judiciary shall extend to all cases respecting the collection of the national revenue, impeachments of any national officers, and questions which involve the national peace and harmony."

In August a draft Constitution was drawn up, in which an endeavour was made to create two national tribunals of final authority. Disputes between the States involving questions of jurisdiction or territory were to be referred to the Senate, together with private controversies concerning land claimed under conflicting grants from different States. All other cases were to be decided by the Supreme Court and the inferior Federal tribunals.

This unsatisfactory dualism did not survive debate, and ultimately the jurisdiction of the Senate was taken away, except its power to hear impeachments. On the I7th 
September, 1787 , the Constitution in its present form was signed by thirty-nine out of the sixty-five delegates who had been appointed to the Convention. By June of the next year it had received ratifications from nine States, which was the minimum number required under its own terms (Art. VII) to bring it into force. Rhode Island, the smallest and most intractable of the States, held out longest and ultimately ratified on the 29th May, I79o. The Constitution thereupon became binding on the whole country, and each of the younger States has since become a consenting party to the Constitution by the fact of its admission to the Union.

The third Article creates the national judiciary in the following terms:

"Section I. The judicial power of the United States shall be vested in one Supreme Court, and in such inferior courts as the Congress may from time to time ordain and establish. The judges, both of the Supreme and inferior courts, shall hold their offices during good behaviour, and shall, at stated times, receive for their services a compensation, which shall not be diminished during their continuance in office.

"Section 2. The judicial power shall extend to all cases, in law and equity, arising under this Constitution, the laws of the United States, and treaties made, or which shall be made, under their authority; to all cases affecting ambassadors, other public ministers, and consuls; to all cases of admiralty and maritime jurisdiction; to controversies to which the United States shall be a party; to controversies between two or more States; between a State and citizens of another State; between citizens of different States,--between citizens of the same State claiming lands under grants of different States, and between a State, or the citizens thereof, and foreign States, citizens, or subjects.

"In all cases affecting ambassadors, other public 
ministers, and consuls, and those in which a State shall be party, the Supreme Court shall have original jurisdiction. In all the other cases before mentioned, the Supreme Court shall have appellate jurisdiction, both as to law and fact, with such exceptions, and under such regulations as the Congress shall make."

(The remaining provisions deal with criminal a:ses.)

In ursuance of the authority thus conferred Congress procee 'ed to pass the Judiciary Act of 1789 , providing for the establishment of a complete system of Federal courts throughout the whole country. Of this Act it is necessary to cite the fourteenth section:

"The Supreme Court shall have exclusive jurisdiction of all controversies of a civil nature, where a State is a party, except between a State and its citizens; and except also between a State and citizens of other States, or aliens, in which latter cases it shall have original but not exclusive jurisdiction."

Again, it will be observed, no express provision is made, either in the Constitution itself or in the Act of Congress, for ensuring the compliance of States with the decrees of the Court.

In the debates preceding the ratification of the Constitution by the various States strong opposition to the whole idea of a Federal Supreme Court appeared in many quarters. In particular objection was expressed that the provisions of the Article might expose a sovereign State to the indignity of being summoned to the bar of the Court at the suit of a private litigant. John Marshall, afterwards Chief Justice of the United States, and other speakers poured ridicule upon this argument, saying in effect that no one ever contemplated such an absurdity, and it is certain that the public opinion of the day would 
never have consented to such an infraction of State rights. ${ }^{1}$

Marshall, however, was for once in the wrong. In 1792 a suit was actually filed in the Supreme Court by one Chisholm of South Carolina against the State of Georgia, the claim being for certain moneys due to an estate of which the plaintiff was executor. Georgia refused to appear, but the case came on for argument in the rext year, and a majority of the Court held that the : tion was maintainable. ${ }^{2}$ This decision created widespread indignation throughout the Union, for it was clearly contrary to the understanding upon which the great majority of Americans had consented to the establishment of a Supreme Court and a Federal judiciary. In Georgia feeling ran so high that a bill was actually introduced into the Legislature threatening with the death penalty any one who should attempt to enforce the judgment. Next year Congress took action to overrule the judgment by the Eleventh Amendment to the Constitution, which became effective in 1798 . The Amendment runs as follows:

"The judicial power of the United States shall not be construed to extend to any suit in law or equity, commenced or prosecuted against one of the United States by citizens of another State, or by citizens or subjects of any foreign State."

Various attempts were made to circumvent the prohibitory effect of the Amendment, either by bringing suit against a State official as nominal defendant or by a State lending its name to a private plaintiff for the prosecution of what was really a private claim. These attempts, however, failed. The Court in each case looked at the sub-

1 See p. IOI, post.

22 Dallas, 419. 
stance of the action rather than the form, and invariably rejected all such claims as were in substance suits by individuals against States. The details of these attempts belong rather to the study of American constitutional law than to the history of the Court in its international character.

A few words may be added as to the personnel of the Court. The original establishment provided for a chief justice and five associate justices; the full number at the present day is nine. The judges are irremovable except upon impeachment, their tenure thus being slightly more secure than that even of the British judges, who can be removed upon an address from both Houses of Parliament. Their salaries cannot be reduced during their term of office. Up to the present there has been only one attempt to impeach a judge of the Supreme Court, Samuel Chase of Maryland, and this was defeated in I 805 , though two convictions have been obtained against inferior Federal judges. ${ }^{2}$

Washington was keenly sensible of his high responsibility in making his original appointments to the Court, and his selection was amply justified by events. The first Chief Justice was John Jay of New York, and the associates were James Wilson of Pennsylvania, William Cushing of Massachusetts, John Blair of Virginia, James Iredell of North Carolina, and Thomas Johnson of Maryland. In the course of its history the Court has included many eminent men, but space only permits us here to notice one, John Marshall of Virginia, who presided over it from I8o I until I 835. Marshall has by common consent now won a permanent place among the great lawyers of the world. To him, more than to any other man,

1 The attack on Chase was a purely political attempt to punish the Court for its "Federalist" leanings. Of the two convictions one was for personal misconduct and one for rebellion. 
America owes that progressive interpretation of the Constitution which has enabled it to keep pace with the needs of a community that has grown far beyond anything that its founders could have imagined.

No other tribunal in the world's history has hitherto been entrusted with responsibilities so high as those of the Supreme Court, and men who to-day are contemplating the settlement of all international disputes by judicial means may well ask how far the actual history of the Court has justified the confidence reposed in it by its authors. ${ }^{1}$

It is not altogether easy to give an unqualified answer. At the outset much suspicion and hostility had to be overcome, and the successful resistance of Georgia to the Chisholm judgment affords a fair measure of popular feeling in Revolutionary times. Again in 1857 a great outbreak of resentment was provoked by the decision in the Dred Scott case, ${ }^{2}$ when a majority of the Court held that a slave returning from a free Territory to a slave State was still a slave and as such without civil rights. This doctrine was formally condemned by the Republican Convention which nominated Lincoln in 1860 , and must undoubtedly be reckoned among the causes which contributed to the Civil War. In two other notable political cases where strong party feeling was aroused the judges of the Court were divided in opinion along strictly party lines. In one of these, the "Legal Tender Case" 3 of I87I, the Court actually reversed by a majority of five to four its own decision of the previous year, ${ }^{4}$ which had been rendered by a majority of five to three. The death of one judge and two new appointments to the bench had sufficed to turn the balance. In the other instance, that

1 This topic is treated more at length in Chapter VII.

2 Scott v. Sandford, I9 Howard, 393. See p. 9I, post.

3 I2 Wallace, 457.

4 Hetburn v. Griswold, 8 Wallace, 603. 
of a disputed presidential election in 1877 , five judges of the Court were included in the commission of inquiry, and they voted on purely party lines just as did the nonjudicial members.

On the other hand, it will be found that no such doubtful motives appear to have affected the decisions of the Court in any of the inter-State cases which we shall examine in the following chapters. In direct suits between two States the Court has always shown a high standard of impartiality, and judges have more than once voted against the contentions of the States to which they themselves belonged. The confidence of the States in the Court has deepened with the advance of time, and they have shown an increasing willingness to submit their disputes to its decision.

Before parting from this question it is necessary to bear in mind that the Court did not prevent, and was given no opportunity of preventing, the Civil War. The immediate dispute in the Civil War turned, nọt upon the ethics of slavery, but upon the right claimed for the Southern States to withdraw from the Union. That question had been left open by the Constitution, and if it ever had come before the Supreme Court we may be certain that neither party would have tamely submitted to an adverse decision. The issue was clearly defined on the 20th December, I860, when the South Carolina Convention repealed the ordinance ratifying the Constitution, and declared that South Carolina resumed her sovereign place among the nations. Other Southern States quickly followed suit, and it is obvious that, if they were right in their contention, the jurisdiction of the Supreme Court over the controversy was annulled by the mere fact of secession. As a matter of fact the South was fully determined to fight, if necessary, in support of its claim, and Northern opinion, after a certain amount of hesi- 
tancy, arrived at an equally strong determination to fight for the Union. Ultimately the matter was settled by war, and the victory of the North was recorded in three Amendments ${ }^{1}$ to the Constitution.

The moral of this surely is that no lews and no law courts upon earth can in the last resort restrain States or nations who are fully determined to fight rather than to forego what they consider to be their just claims. The ultimate cure for war lies, not in any particular judicial machinery, but in the growth among all nations of a willingness to settle controversies by judicial rather than by warlike methods.

This is not a merely cynical conclusion, nor does it justify us in saying that there is no sphere of usefulness for an international court. Any war is a terrible thing, and a court which cannot prevent all wars will have justified its existence if it even succeeds in preventing one.

In the following chapters we shall try to discover how far American experience justifies us in putting our hopes in a permanent international court as a means of preserving peace among the nations of the world.

1 13th, 1865; 14th, 1868; I5th, I870. The last, which purports to give the negroes equal suffrage with whites. has been nullified in practice by the ingenuity of Southern statesmen. 


\section{CHAPTER II}

\section{EXTENT OF THE JURISDICTION}

THE third Article of the Constitution was drafted in somewhat general terms, and many points were left to be settled by the Court itself as they should arise. This was probably inevitable. Any attempt to work out every conceivable problem in 1787 would undoubtedly have prevented any agreement upon the main question of the acceptance of the Constitution. The first necessity was to induce the suspicious States to accept any Court at all. That being done it would remain with the Court itself to justify its existence in the eyes of the American people by the wisdom and fairness of its decisions.

Under the Confederation only one inter-State dispute was decided by the commission procedure already described. Eleven boundary cases, mostly of long standing, remained unsettled when the Confederation was succeeded by the "more perfect union" of the present Constitution.

The States, however, showed no undue eagerness to appeal to the new tribunal, and it was not until I 846 that the first final decree was entered in a suit between two States. The earliest cases deal only with small points of procedure, and are therefore of scarcely more than technical interest. In 1799 New York filed a suit against Connecticut ${ }^{1}$ arising out of a boundary dispute, and in I 830 an action was begun by New Jersey against New York. ${ }^{2}$ Neither suit was prosecuted beyond the initial

${ }^{1} 4$ Dallas, I.

23 Peters, 46r. 
stages. As the Constitution had said nothing about procedure, the Court was left to find its own way, and this being so it was natural that judges who had been brought up on the English common law should model their procedure as far as possible upon the existing practice of the English courts. Accordingly it was laid down

" that this court consider the practice of the court of king's bench and of chancery, in England, as affording outlines for the practice of this court; and that they will, from time to time, make such alterations therein, as circumstances may render necessary." 1

It is only necessary to add that the Court, in handling these questions of procedure, felt its way forward with the utmost caution, and with a keen sense of the dignity of the parties before its bar.

In passing we may notice a case decided in $183 \mathrm{I}$, in which the Cherokee Indians sought the aid of the Supreme Court to put an end to the continued persecution to which they were subjected by the State of Georgia. ${ }^{2}$ Persistent ill-treatment of the Indian tribes forms an unpleasing feature of early American history, and upon the merits of the case it is evident that there was only too good foundation for the Cherokee claim. But the question of jurisdiction turned upon whether the Indian tribes were entitled to be regarded as "foreign States" within the meaning of the phrase in Article III of the Constitution. This question a majority of the Court answered in the negative, though Marshall took the opportunity of expressing in strong language the indignation felt by the whole Court at the treatment to which the unfortunate Cherokees had been subjected.

The great question of jurisdiction to entertain a suit

15 Peters, 284-5.

25 Peters, I. See pp. 72-5, post. 
between two States was first fully argued and decided in the case of Rhode Island v. Massachusctts, which began in $1833,{ }^{1}$ but did not reach a final judgment until $\mathrm{I} 846 .{ }^{2}$ The suit was brought to determine a boundary dispute of nearly two hundred years standing, and to the ordinary reader it would appear that this was precisely the kind of controversy which was intended by the Constitution to be decided in the Supreme Court. But the doctrine of State sovereignty was tenaciously held for long after the Revolution, and Massachusetts contended strenwously and ingeniously for the view that the question did not fall within the jurisdiction of the Court. Counsel maintained that the dispute was wholly political in its nature, and that the Court could not determine political controversies; that no law existed to govern the case; that there was no procedure applicable to it; and that there was no means of enforcing the decision of the Court.

These arguments found favour in the eyes of Chief Justice Taney, who was an ardent believer in the doctrine of State rights, but were decisively overruled by the majority of the Court. The jurisdiction, as Mr. Justice Baldwin pointed out, was derived from the consent of the several States when they accepted the Constitution; and as a matter of history it was easy to show that boundary disputes were the commonest causes of controversy and those which it was especially desired to submit to judicial decision. Since diplomatic intercourse was forbidden to the States by the first Article (Sec. Io) of the Constitution it was clear that such controversies could not be peaceably terminated except by judicial means. So far as matters of law were concerned, the question could be treated just as if it were a boundary case between two private landowners. Questions political in their origin

${ }^{1} 7$ Peters, 651.

24 Howard, 59r. 
could become judicial by submission to a proper tribunal. Procedure could be regulated by following the English practice, subject to any necessary modifications. One passage from the judgment may well be quoted:

"We are thus pointed to the true boundary line between political and judicial power, and questions. A sovereign decides by his own will, which is the supreme law within his own boundary; a court or judge decides according to the law prescribed by the sovereign power, and that law is the rule for judgment. The submission by the sovereigns or states to a court of law or equity of a controversy between them, without prescribing any rule of decision, gives power to decide according to the appropriate law of the case, which depends on the subject matter, the source and nature of the claims of the parties, and the law which governs them. From the time of such submission the question ceases to be a political one to be determined by the sic volo, sic jubeo of political power; it comes to the court to be decided by its judgment, legal discretion, and solemn consideration of the rules of law appropriate to its nature as a judicial question, depending on the exercise of judicial power; as it is bound to act by known and settled principles of national or municipal jurisprudence, as the case requires."

The question of jurisdiction was determined in 1838 , but the case dragged on for many years, Massachusetts raising every kind of technical delay in order to evade or postpone a decision on the merits. Ultimately the cause came on for final hearing in 1846 , and the judgment of the Court was delivered in favour of Massachusetts, mainly on the ground of long possession of the disputed territory.

In the next case, that of Missouri v. Iow ${ }^{2}$ in 1849 , no question of jurisdiction arose, as the bill was filed by

1 I2 Peters, 737.

P. 4345

B

27 Howard, 660. 
consent of both parties in order to settle a question of boundary. In I 850 another boundary suit was filed by Florida against Georgia, ${ }^{1}$ in which again no objection was raised to the jurisdiction. The case however merits attention because of the successful claim made by the United States to intervene in the action, when the case came on for argument in $1854 .^{2}$ This claim was based partly on the ground that the validity of Federal grants was involved and partly on the interest which the Federal government had, on behalf of itself and all the other States, in seeing that any question of State boundaries was correctly decided. Technically such a claim was open to objection, because the United States desired to intervene and produce evidence without assuming the liabilities of a party to the action. The Federal contention was opposed by both the parties to the suit, but a majority of the Court decided to disregard technical objections and to admit the intervention. The case is interesting because it illustrates what has always been the consistent policy of the Court in handling inter-State controversiesnamely, a refusal to allow the technical rules of procedure which obtain in private cases to interfere with a full consideration of every case upon its substantial merits.

The jurisdiction was again asserted after argument in $1860^{3}$ in a case where Kentucky sought to compel the Governor of Ohio by mandamus to deliver up for trial a free negro who was accused of violating the Kentucky law by assisting the escape of a slave. Feeling on the slavery question ran high in 1860 , and it was abundantly clear that nothing short of superior force would induce the authorities of Ohio to deliver up the fugitive. The Court affirmed its jurisdiction to hear the case, and held that the action against the Governor was in substance an

I I I Howard, 293.

2 I7 Howard, 478.

${ }^{3}$ Kentucky v. Dennison, Governor of Ohio; 24 Howard, 66. 
action against the State. Procedure, it was again laid down, was a matter entirely within the discretion of the Court, and the procedure by mandamus was the most appropriate in the particular case. They went on to say that the text of the Constitution imposed upon the Governor an absolute obligation to deliver up all fugitives from justice, irrespective of the offence with which they were charged, and he was not entitled to exercise any discretion in the matter. But although this was so, the Court held that there was no means provided by the law for enforcing the obligation.

"The performance of this duty, however, is left to depend on the fidelity of the State Executive to the compact entered into with the other States when it adopted the Constitution of the United States, and became a member of the Union. . . . If the Governor of Ohio refuses to discharge this duty, there is no power delegated to the General Government, either through the Judicial Department or through any other Department, to use any coercive means to compel him. And upon this ground the motion for the mandamus must be overruled." 1

The next case raising the question of jurisdiction came after the Civil War and arose out of it. During the war, in the year $\mathrm{r} 86 \mathrm{I}$, the people of the mountain counties in the northwest of Virginia broke off from the main body of that State and erected themselves into a new State under the title of West Virginia. The draft constitution provided that two counties, the sympathies of which were doubtful, might have the option of joining the new State by plébiscite. Legal assent to this arrangement was given in May, 1862 , by a body which Congress recognised as the lawful legislature of Virginia, though in fact it only represented the minority of Virginians whose

124 Howard, 1og-Io. See Chapter VI, post. 
sympathies were with the North. The consent of Congress having been duly obtained, a new State of the Union came into existence on the 2oth April, I863. Shortly afterwards the two doubtful counties voted for inclusion in West Virginia, and were duly handed over with the cordial consent of the minority legislature of the parent State. In I866 Congress passed an act recognising the transfer.

In the eastern theatre of war fighting ended with Lee's surrender to Grant at Appomattox in April, I865. In December of the same year the legislature of Virginia, which now again really represented the people, passed an act repealing the acts under which the two counties had been transferred. This was followed up by a suit in the Supreme Court against West Virginia, ${ }^{1}$ which came on for argument in 1870 .

West Virginia demurred to the jurisdiction on the same ground as that taken by Massachusetts in 1838 , namely, that the question was in its nature not judicial, but purely political. In view of the earlier cases there could be but one answer to this contention.

"We consider, therefore," said Mr. Justice Miller for the majority of the Court, " the established doctrine of this Court to be, that it has jurisdiction of questions of boundary between two States of this Union, and that this jurisdiction is not defeated, because in deciding that question it becomes necessary to examine into and construe compacts or agreements between those States, or because the decree which the Court may render affects the territorial limits of the political jurisdiction and sovereignty of the States which are parties to the proceeding." ${ }_{2}$

Upon the merits of the case the Court held that Virginia was bound by the acts of her minority legislature, to 1 II Wallace, 39. 
which Congress had assented. The two counties were therefore adjudged to West Virginia.

The jurisdiction of the Court was now well established, and no new question arose for many years. The case of New Hampshire v. Louisiana ${ }^{1}$ in 1883 needs no more than a passing notice, because it was not so much a controversy between States as an attempt on the part of individuals, with the connivance of a State, to evade the Eleventh Amendment. The case arose out of the inability or unwillingness of Louisiana to meet her liabilities on certain bonds, which were held by citizens of New Hampshire and New York. Being unable to sue in their own names the holders made an arrangement, confirmed by statute, with their respective State authorities, by which the bonds were to be nominally assigned to the State, and the State was to bring suit for the sums due. The whole benefit, risks, and costs of the proceedings were to be borne by the bondholders in spite of the assignment. Upon these facts the Court had no difficulty in finding that the assignment was merely colourable, that the real title remained in the bondholders, and that the suits were in substance brought in defiance of the Amendment.

This case may be compared with a somewhat similar one of South Dakota v. Nortl Carolina, ${ }^{2}$ decided in 1904. In this case the bondholders made a free gift of their bonds to South Dakota, and reserved to themselves no kind of right or interest in any proceedings that might subsequently be taken. The gifts were of course made with the object of enabling the State to sue upon the bonds, and the donors expressed a wish that the proceeds might be devoted to State charities. North Carolina strenuously argued that this case came within the prin-

${ }^{1} 103$ U. S., 76.

2 IQ2 U. S., 286. See pp. 63, 98, post. 
ciple of the earlier decision, and so fell within the prohibition of the Eleventh Amendment. The majority of the Court, however, held that neither the motive prompting the action nor the status of the donor affected the validity of the gift, so long as title genuinely passed. A "controversy between States" having arisen, the jurisdiction of the Supreme Court to decide it was affirmed, and a decree of foreclosure was accordingly made against North Carolina.

The jurisdiction of the Court to determine boundary disputes having been firmly established, we may pass over a series of boundary cases in which no objection to the jurisdiction was raised by either party. A new problem was, however, presented by the case of Louisiana v. Texas, ${ }^{1}$ which came before the Court in 1900 . The complaint in this case was that the quarantine laws of Texas, instead of being honestly aimed at the protection of the public health, were in reality aimed at diverting profitable trade from the port of New Orleans in Louisiana to the port of Galveston in Texas. A complete embargo had been placed upon all traffic entering Texas from New Orleans, although the medical reasons were quite insufficient to justify such stringent action. This, it was claimed by Louisiana, was an attempt by Texas to regulate inter-State commerce, a right reserved under the Constitution to the United States.

The Court, however, refused to entertain the suit. The main reason given for this decision was that the controversy was not one "between States," but was really an attempt to sue Texas for an injury suffered by certain commercial firms of New Orleans. The Court declined to accept the view that Louisiana was entitled to sue as "parens patriac, trustee, guardian, or representative of all her citizens." The technical ground was also taken

${ }^{1}$ I76 U. S., I. 
that Texas had not so far adopted or authorised the action of her health officer as to make it her own State action.

A proverb tells us that it is the duty of a good judge to enlarge his jurisdiction, and the decision of the Supreme Court in this case does not seem easy to reconcile with the principles which had hitherto guided its rulings. The opinion was not that of an unanimous Court. Two judges who concurred in the result did so for different reasons, while $\mathrm{Mr}$. Justice Brown, though concurring on technical grounds, maintained strongly the right and duty of a State to protect its individual citizens against foreign oppression.

"In view," he said, "of the solicitude which from time immemorial States have manifested for the interest of their own citizens; of the fact that wars are frequently waged by States in vindication of individual rights, of which the last war with England, the opium war of 1840 between Great Britain and China, and the war which is now being carried on in South Africa between Great Britain and the Transvaal Republic, are all notable examples; of the further fact that treaties are entered into for the protection of individual rights, that international tribunals are constantly being established for the settlement of rights of private parties, it would seem a strange anomaly if a State of this Union, which is prohibited by the Constitution from levying war upon another State, could not invoke the authority of this Court by suit to raise an embargo which had been established by another State against its citizens and their property. An embargo, though not an act of war, is frequently resorted to as preliminary to a declaration of war, and may be treated under certain circumstances as a sufficient casus belli. The case made by the bill is the extreme one of a total stoppage of all commerce between the most important city in Louisiana and the entire State of Texas; and 
while I fully agree that resort cannot be had to this Court to vindicate the rights of individual citizens, or any particular number of individuals, where a State has presumed to prohibit all kinds of commerce with the chief city of another State, I think her motive for doing so is the proper subject of judicial inquiry." 1

Whichever view be taken, the principle involved is obviously of international importance. It is possible that the majority of the judges were not entirely confident of the soundness of their decision, for a judgment pronounced in a somewhat similar case only two years later seems to rest upon different and firmer ground.

The case of Kansas v. Colorado, ${ }^{2}$ decided in I902, arose out of a complaint by Kansas that Colorado was wrongfully diverting the waters of the Arkansas River, which flowed through the territory of both States. The object of the diversion was to irrigate the dry lands of Colorado, but this had the result, so it was claimed, of impairing the fertility of Kansas. Colorado denied the jurisdiction on the ground, successfully maintained by Texas in the earlier case, that the suit was really brought to protect the interests of private landowners in the State of Kansas. The plaintiff State presented her claim both as an individual landowner, and on behalf of her citizens affected by the diversion of the stream. The Court, without attempting to distinguish the earlier case, held that the facts alleged presented a "controversy between States" suitable for determination by the Supreme Court, and consequently affirmed the jurisdiction.

The ordinary layman would no doubt consider that of these two cases Louisiana v. Texas presented the stronger reasons for the intervention of the Supreme Court. In

${ }^{1} 176$ U. S., 27.

2 I 85 U. S., I25. See p. 8I, post. 
Kansas v. Colorado there was at the most a legitimate conflict of interests between two riparian proprietors as to the use of a flowing stream-a kind of dispute with which the courts are familiar in ordinary life. There was no suggestion that the action of Colorado was inspired by any hostility towards Kansas. But in the earlier case, if the plaintiff's statement proved to be correct, the policy of Texas was actuated by a desire to destroy, under the pretext of quarantine laws, the entire commerce of New Orleans. This is the kind of action which in international affairs leads to war; and since the main object of an international Court is the prevention of war, it seems difficult to understand why the Supreme Court refused even to investigate Louisiana's complaint. The injury complained of in the later case, as in the earlier, was purely to proprietary rights, and the judgment of the Court does not seem to have turned upon the fact that a small piece of the land involved was owned by the State of Kansas itself.

The real explanation of Kansas v. Colorado is to be found in the intervening case of Missouri v. Illinois, ${ }^{1}$ decided in Igor. The complaint of Missouri in this action was that Illinois was polluting the Mississippi by discharging crude sewage into it through the Illinois River, and thus injuring the health of the people of Missouri. Illinois, like Texas, demurred to the jurisdiction on the ground that the interests of individuals only were affected and that the question did not concern Missouri as a State.

The Court, however, affirmed its jurisdiction to hear the case. Mr. Justice Shiras, who delivered the judgment of the majority, naturally felt the embarrassment caused by the Louisiana decision, and laboriously endeavoured to distinguish it from the case before him.

${ }^{1}$ I80 U. S., 208. See p. 79, post. 
His somewhat elaborate explanation may be thus summarised in his own words:

"The Court [in Louisiana v. Texas] did not decline jurisdiction, but exercised it in holding that the facts alleged in the bill did not justify the Court in granting the relief prayed for." 1

This is by no means easy to reconcile with the actual language of the Court in the earlier case, but it is scarcely worth while analysing the matter too closely from the point of view of legal consistency. What really happened was that the judges changed their minds, and took a broader view of the extent of their own jurisdiction. It may be remarked that Chief Justice Fuller and two other judges dissented from the decision in Missouri v. Illinois, holding that no "controversy between States" was presented. In Kansas v. Colorado the judgment was unanimous, and it is evident that the sound reasoning of Mr. Justice Brown in Louisiana v. Texas had gradually won its way to general acceptance.

It will be observed that by 1902 the Court had thrown over all remnants of the timidity with which by a majority it had ventured to assume jurisdiction of a boundary case in 1838 . At the present day it is probably true to say that there is no genuine dispute between two States which the Court is not prepared to decide, if the facts are presented to it in proper form.

A half-hearted attempt to challenge the jurisdiction was made in 1906, when Louisiana filed a bill against Mississippi ${ }^{2}$ to determine the boundary within which each State might regulate the fisheries in an arm of the sea called Mississippi Sound. The objection raised by Mississippi came sixty years too late, and was easily overruled. It is, however, worth remarking that, when ${ }^{1}$ I 80 U. S., 240.

2202 U. S., I. See p. 47 , post. 
the dispute arose, each party organised armed patrols to enforce its rights, and an armed conflict was really only averted by the confidence which each of the disputants felt in the Supreme Court.

There remains to be considered only one case of a dispute between States in which the jurisdiction of the Court was again questioned. This is the great case of Virginia v. West Virginia, ${ }^{1}$ which in its various aspects has engaged the attention of the Supreme Court repeatedly since I906.

Like the earlier case between the same parties, to which reference has already been made, ${ }^{2}$ this dispute arose out of the separation of West Virginia from the parent State during the Civil War. The Wheeling Convention of I86I, which organised the separation, undertook that the new State should assume a just proportion of the public debt of Virginia contracted prior to the Ist January, I86I. This undertaking was repeated in the Constitution of West Virginia, where it was coupled with a promise that the legislature should ascertain the amount of the debt " as soon as may be practicable," and provide for its discharge. The substance of Virginia's case is thus stated by Chief Justice Fuller:

"From I 865 to 1905 various efforts were made by Virginia through its constituted authorities to effect an adjustment and settlement with West Virginia for an equitable proportion of the public debt of the undivided State, proper to be borne and paid by West Virginia, but all these efforts proved unavailing, and it is charged that West Virginia refused or failed to take any action or do anything for the purpose of bringing about a settlement or adjustment with Virginia. The original jurisdiction of this Court was therefore invoked by Virginia to

1206 U. S., 290 . See pp. 67, 99, post.

2 I I Wallace, 39. Ante, p. ig. 
procure a decree for an accounting as between the two States, and, in order to a full and correct adjustment of the accounts, the adjudication and determination of the amount due Virginia by West Virginia in the premises." 1

In demurring to the jurisdiction West Virginia maintained that the facts alleged did not constitute a " controversy between States" in the sense contemplated by the Constitution; that there was no means of enforcing a final decree for the sum due; and that the proviso in her Constitution, sanctioned by Congress, for ascertaining the amount of the debt by the action of her legislature took the matter out of the jurisdiction of the Supreme Court.

In view of the recorded decisions of the Court it was impossible to expect that such contentions should prevail, and they were decisively rejected by an unanimous Court. With regard to the question of enforcing the decree Chief Justice Fuller said "that it is not to be presumed on demurrer that West Virginia would refuse to carry out the decree of this Court," " though the Court might have to consider the course to be adopted in the event of such an unpleasant emergency actually arising. This decision was rendered in 1907, and the judges who gave it doubtless felt perfectly confident that any decree which they might make would be unhesitatingly obeyed by any State in the Union. Unfortunately these hopes have not been realised. A final decree for a large sum was made against West Virginia in June, I9I5, but for nearly four years all attempts to obtain payment have failed, and it seemed likely that the Supreme Court would be faced with the chief difficulty that must always confront any international court, the difficulty of enforcing compliance with its own judgments. At the time of writing, how-

1206 U. S., 317.

2206 U. S., 319. 
ever, it is gratifying to know that wiser counsels have prevailed, and provision is now (1919) being made by the West Virginia legislature to satisfy the decree.

The only question remaining to be considered under the head of jurisdiction is the position before the Supreme Court of the United States itself. Under the Constitution ${ }^{1}$ the jurisdiction extends " to controversies to which the United States shall be a party; to controversies between two or more States; . . ." What is the exact meaning to be attached to these words?

The first case of suit by the United States against a State occurred in I890, when the Federal authorities brought an action of debt against North Carolina ${ }^{2}$ upon certain unpaid bonds of that State. No objection was taken to the jurisdiction in this case, which therefore need not detain us further. But two years later the right of the United States to sue a State was strongly, though unsuccessfully, challenged by the State of Texas.

The bill in this case ${ }^{3}$ was filed to determine whether a certain area of country formed part of the State of Texas or of the Federal territory of Oklahoma. The case turned mainly upon the terms of several treaties and upon a great deal of geographical evidence, such as the value of various maps and surveys. Texas not only denied the Federal title to the land, but also denied the jurisdiction of the Supreme Court to hear the case.

Her argument ran as follows: A sovereign State can only be sued by its own consent, and the only consent is that to be found in the terms of the Constitution. The consent given there can only be read as a consent to suit by other States. Express consent would be required to a suit by the United States, for this would not be a suit between equals, since the Federal Government would

2 See p. 7 , ante.

2 I36 U. S., $2 \mathrm{I}$. See p. 6I, post.

${ }^{3}$ I 43 U. S., 621 . See p. 44 , post. 
have the advantage in a Federal Court. It was further said that the question was political, not judicial, in its nature, and certain objections of a technical kind were also raised. Historically there was good support for this argument in the fact that at the Philadelphia Convention proposals for expressly giving the Court jurisdiction in controversies between the United States and a State had been deliberately rejected by the delegates.

The majority of the Court, in rejecting the Texan claim, relied mainly upon the words of the Constitution which give the Court jurisdiction " in all cases . . . in which a State shall be a party." But they were also impressed by what may be called the practical argument, that if jurisdiction were refused, the only alternatives would be to settle the dispute either by agreement, of which there was no prospect, or by suit in a Texan Court with the consent of Texas, or in the last resort by war.

The jurisdiction was accordingly affirmed. It is perhaps questionable whether such a decision would have entirely pleased the men of 1787 , but its practical convenience and good sense in the twentieth century cannot be disputed. "It would be difficult," said Mr. Justice Harlan for the majority of the Court, " to suggest any reason why this Court should have jurisdiction to determine questions of boundary between two or more States, but not jurisdiction of controversies of like character between the United States and a State." 1

It should be added that Chief Justice Fuller and Mr. Justice Lamar dissented from this decision.

It being clearly established that the United States could sue a State of the Union in the Supreme Court, the question has arisen whether the converse also holds good, enabling a State to bring the United States to the bar of the Court as an unwilling defendant. This problem was

${ }^{1} 143$ U. S., 645. 
first presented by the case of Kansas v. United States, ${ }^{1}$ decided in 1907. The dispute concerned the ownership of certain lands which had been granted by Federal statute for the purpose of railroad construction. Counsel for the United States demurred to the jurisdiction, partly on the ground that Kansas was only a nominal party, and partly on the ground that the United States had not consented to be sued. With regard to the latter point the question of jurisdiction is not altogether clear. In an earlier case, referred to in the opinion of the Court, Mr. Justice Brewer had said :

"The silence of counsel does not waive the question, nor would the express consent of the parties give to this Court a jurisdiction which was not warranted by the Constitution and laws. It is the duty of every court of its own motion to inquire into the matter irrespective of the wishes of the parties, and be careful that it exercises no powers save those conferred by law. Consent may waive an objection so far as respects the person, but it cannot invest a court with a jurisdiction which it does not by law possess over the subject-matter." 2

In the present case the Court dismissed the bill for want of jurisdiction ${ }^{3}$ on the ground that the United States had not consented to be sued. This decision is not quite easy to reconcile with the dictum just quoted that even consent cannot confer a jurisdiction which does not exist. The distinction drawn by the Court would appear to be that in order to give jurisdiction the consent must be by statute, either general or special; a consent on the part of the executive authority is not sufficient.

Such a general consent was given in 1855 by the Act of Congress creating the Court of Claims, a tribunal

1204 U. S., 343.

2 Minnesota v. Hitchcock, 185 U. S., 387.

3204 U. S., 33I. 
formed to enable contractual and similar claims against the United States to be settled by judicial rather than by executive or legislative authority. Before this Court was set up the strict application of the doctrine of sovereignty favoured in America rendered it impossible for a citizen to obtain judicial investigation of any claim which he might have against the Federal Government. As an eminent judge of the Court once remarked: "The government of the United States holds itself, of nearly all governments, the least amenable to the law."

In England the Crown is nominally exempt from suit except by its own consent, but in practice the procedure known as "petition of right" enables any contractual claim against the Crown to be prosecuted with the same certainty of judicial treatment as obtains in a suit between private parties. Since the American Constitution was designed to be, in Marshall's phrase, "a government of laws, and not of men," it is perhaps remarkable that so long a time was suffered to elapse before any effective remedy was provided against the failure of executive authorities to meet their obligations.

The statutes constituting the Court did not expressly provide for the case of claims by a State against the Federal Government, and the jurisdiction of the Court to hear such suits was disputed by the United States when the question first arose upon a claim presented by Louisiana in I887. ${ }^{1}$ The jurisdiction was, however, affirmed upon appeal by the Supreme Court, and has since been exercised in several similar cases.

We have already noticed in passing the case of Florida v. Georgia, ${ }^{2}$ where the Court permitted the United States to intervene in a boundary dispute between two States on the ground that Federal grants were in question and that the United States had a legitimate interest in seeing that

$x$ I23 U. S., 32.

217 Howard, 478. Ante, p. 18. 
inter-State boundaries were correctly drawn. In this connection it may be added that in 1907 the United States again sought to intervene between two States in the second phase of the case of Kansas v. Colorado, ${ }^{1}$ where Kansas complained of the diversion by Colorado of the waters of the Arkansas River. But in this case the intervention was disallowed by the Court on the ground that the subject-matter of the dispute was not one of those which the Constitution had committed to the care of the Federal Government. The United States has authority to regulate navigable waters, but the diversion complained of did not affect the stream in its navigable portion.

It is clear from the decision in this case that any claim of the United States to intervene in a dispute between two States will be somewhat jealously regarded by the Supreme Court.

1206 U. S., 46. See p. 82, post. 


\section{CHAPTER III}

\section{BOUNDARY CASES}

A study of the map of the United States will show that in the great majority of cases the inter-State boundaries consist either of rivers or of mathematical lines. Thus, for example, the Mississippi gives a frontier to no less than ten States; each of its two principal tributaries, the Ohio and the Missouri, forms the border of five more, and many lesser streams have also been adopted as State boundaries. But even more remarkable is the general prevalence in America of the geometrical frontier. Every State in the Union is in part at least bounded by an arbitrary straight line, and some of the western States have no natural frontiers. Even in the Rocky Mountains there has been but little disposition to follow watershed demarcations, and the lines of latitude or longitude are followed over mountain and valley with a complete disregard of physical possibility.

From this it will be seen that the boundary cases which the Supreme Court is called upon to solve differ considerably from the frontier problems which from time to time confront European statesmen. In Europe these disputes are usually of a purely political character. The difficulty of fixing the limits of Poland, Roumania, or Yugo-Slavia arises not from any uncertainty as to the true course of a river or the accuracy of a survey, but in historical events, strategic or economic requirements, and the conflicting wishes of diverse populations. In America 


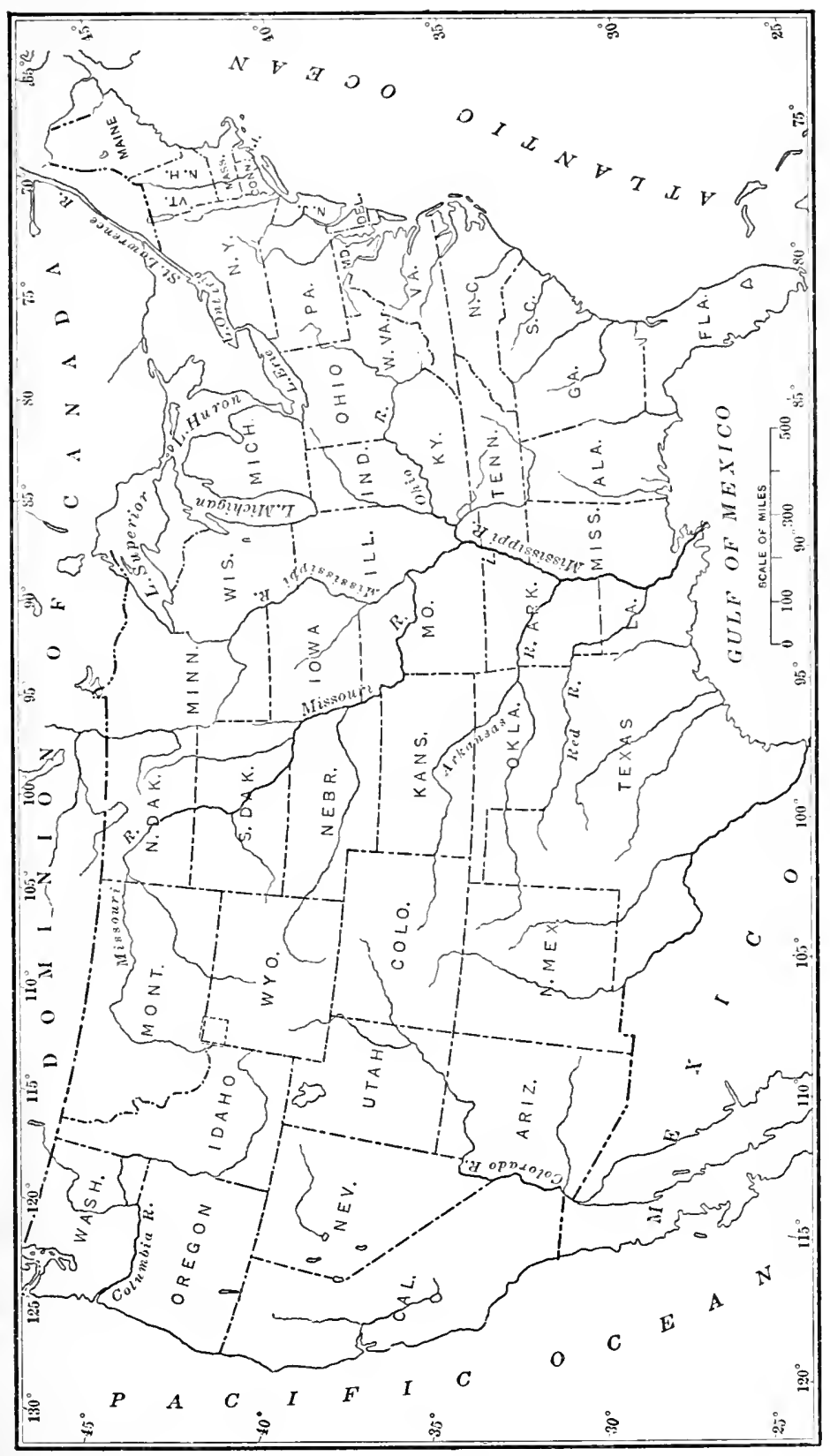



the inter-State boundary disputes, although they have occasionally aroused strong feeling, have never since Revolutionary times been based upon any serious conflict of policy or ideals. ${ }^{1}$ In substance they have for the most part been exactly like disputes between adjoining landowners in the ordinary courts. Of the cases noted in this chapter only one, that of Virginia v. West Virginia in $1870,{ }^{2}$ had its origin in a real political quarrel, and even in that case the solution of the problem in the Supreme Court rested upon the purely legal ground that Virginia had given a valid consent under the Constitution to the transfer of the disputed counties. It will also be observed that in no case has the decision of the Supreme Court been influenced in any way by the wishes of the people in the territory affected by the decision. The argument from long possession has always had great weight with the Court, but neither Court nor counsel has ever appealed to the "right of self-determination." The Court is bound by the Constitution, and the Constitution admits of no argument upon any such ground.

The first boundary case to be settled in the Supreme Court was that of Rhode Island v. Massachusetts, which, after many years of the most dilatory proceedings that can be imagined, was decided in favour of Massachusetts in $1846 .^{3}$ The question between the parties was whether a line drawn in 1642 , and acted upon ever since, constituted the true boundary between the two States. Rhode Island contended that the line as drawn did not carry out the directions of the colonial charters, and that although out of possession for over two centuries she had done nothing to forfeit her claim. Massachusetts denied the

1 Even paralleis of latitude are capable of arousing passion. When the question of the Canada-Oregon boundary came up in 1846 a popular war-cry of the Democratic party was "Fiftyfour forty or fight!"

2 II Wallace, 39.

34 Howard, 59 I. 
plaintiff's construction of the charters, and reliec upon the fact that the existing line had been settled by agreement between the two colonies in 1718 ; in addition she pleaded long possession and the neglect of Rhode Island to assert her claims in good time. Rhode Island admitted the agreement of $\mathrm{I} 7 \mathrm{I} 8$, but pleaded that she had accepted it under a mistake.

The Court held that the fact of any mistake had not been proved, and that Rhode Island was bound by the agreement of I7I8. But the decision in favour of Massachusetts rested mainly on the argument from long and undisturbed possession.

"More than two centuries have passed," said Mr. Justice McLean for the Court, " since Massachusetts claimed and took possession of the territory up to the line established by Woodward and Saffrey. This possession has ever since been steadily maintained, under an assertion of right. It would be difficult to disturb a claim thus sanctioned by time, however unfounded it may have been in its origin. . . . For the security of rights, whether of States or individuals, long possession under a claim of title is protected. And there is no controversy in which this great principle may be involved with greater justice and propriety than in a case of disputed boundary."

The next case in order of time is that of Missouri v. Iore'a, which came before the Court by consent of both States, and was decided in $1849,{ }^{2}$ though the consequential proceedings did not end until $18977^{3}$ The dispute turned upon the true location of an artificial boundary laid down by Congress when it admitted Missouri to the Union in 1820 , and the facts are of little interest to any but surveyors. The procedure adopted is, however,
${ }^{1} 4$ IHoward, 638-9.
27 Howard, 660.
${ }^{3} 165$ U. S., II8. 
worthy of notice, since it became the regular practice of the Court in similar cases. The Court after hearing the evidence and arguments decides upon the general line to be followed. Commissioners are then appointed to survey the actual line upon the ground, and to mark it with suitable monuments. They are directed to make a report to the Supreme Court by a certain clate, and the States have the opportunity of expressing their views upon the report thus presented. If no objection is made or sustained, the commissioners' report is confirmed by the Court, and the line thus surveyed and marked becomes the final boundary between the States. The whole costs of the survey are to be shared equally by the parties.

Florida v. Georgia ( 1854$)^{1}$ has been already noted with regard to the claim made by the United States to intervene in the argument, and is not otherwise of general interest. The next case, that of Alabama v. Georgia in I $859,{ }^{2}$ was a dispute about a river boundary, but the point involved was a small one. The boundary was defined in 1802 by an agreement between the United States and Georgia in the following words:

"West of a line beginning on the western bank of the Chattahoochee River, where the same crosses the boundary between the United States and Spain, running up the said river and along the western bank thereof."

The boundary thus described afterwards became the eastern boundary of the State of Alabama, and the sole question between the parties now was whether the word "bank" was meant to fix the line at the high or at the low water mark in the stream. In seeking for authority upon this problem the Court ranged over a wide field, decided cases, writings of publicists, and dictionaries

1 I7 Howard, 478.

223 Howard, 505. 
being alike laid under contribution. ${ }^{1}$ In the result the Alabama claim of the low water mark was definitely rejected, and Georgia was given the high water mark, exclusive of such ground as is only covered by exceptional floods. The exact words used are as follows :

"This language implies that there is ownership of soil and jurisdiction in Georgia in the bed of the River Chattahoochee, and that the bed of the river is that portion of its soil which is alternately covered and left bare, as there may be an increase or diminution in the supply of water, and which is adequate to contain it at its average and mean stage during the entire year, without reference to the extraordinary freshets of the winter or spring, or the extreme droughts of the summer or autumn." 2

It is perhaps most convenient to treat in this chapter the first case of Virginia v. West Virginia (1870), ${ }^{3}$ though in substance it is not so much a boundary dispute as a question of the validity of a political act. The facts of this case have been briefly referred to in the previous chapter. The Court having overruled the defendant State's demurrer to the jurisdiction, the question for decision was whether Virginia had validly consented to the transfer of the two disputed counties to the new State, and, if so, whether Congress had also given an adequate consent. A majority of the Court held that Virginia was bound by the action of the minority legislature with Northern sympathies which had assented to the transaction in 1862 , and that the repudiation of its act in December, 1865, was of no effect. The consent of

1 Howard observes: "These arguments [of counsel] partook rather of the character of a diplomatic negotiation than a forensic dispute, and the reporter declines to attempt to abbreviate them in a law book" (23 Howard, 510).

223 Howard, 5 I4.

${ }^{3}$ II Wallace, 39. 
Congress was given by a resolution of the Ioth March, I866. Three judges dissented from this decision, and held that Virginia had effectively repealed the acts passed by the minority legislature during the war, since the repealing act was passed before the consent of Congress had been obtained.

It may be observed that in this case the inhabitants of the two counties had by plébiscite signified their wish to belong to West Virginia, but this fact in no way influenced the judgment of the Court. Bound as it was by the terms of the Constitution, the Court would not have been at liberty to consider any such arguments. All it could do was to decide whether all the conditions prescribed for the erection of a new State had been properly fulfilled.

The case of Missouri v. Kentucky, also decided in I $870,{ }^{1}$ is one of several boundary disputes arising out of changes in a river bed. ${ }^{2}$ The treaty of 1763 between Great Britain, France, and Spain, upon which many of the existing State frontiers depend, fixed the middle of the Mississippi as the boundary between the British and the French possessions in North America. Kentucky was admitted to the Union in 1792 , being formed out of territory belonging to Virginia, and the middle of the Mississippi was made her western boundary. Missouri was admitted in 1820 , the same line being taken as her eastern frontier. The dispute related to a piece of land known as Wolf Island, lying in the Mississippi about twenty miles below the mouth of the Ohio. Originally the main stream of the river flowed west of Wolf Island, and the eastern or Kentucky channel was only occasionally

1 I I Wallace, 395.

2 Cases arising out of the same cause are very common in the courts of British India, and have been decided upon substantially the same principles as have guided the Supreme Court. The diversions of the great Indian rivers are of ten much more extensive than those described in this chapter. 
navigable. In the course of time the river gradually shifted, until at the date of the suit the main stream flowed east of the island. Jurisdiction over the land in question had at all times been exercised by Kentucky. Upon these facts the Court unanimonsly decided in favour of Kentucky, the law being thus laid down by Mr. Justice Davis:

"If Wolf Island in 1763 or in 1820 or at any intermediate period between these dates, was east of this line, the jurisdiction of Kentucky rightfully attached to it. If the river has subsequentiy turned its course, and now runs east of the island, the status of the parties to this controversy is not altered by it, for the channel which the river abandoned remains, as before, the boundary between the States, and the island does not, in consequence of this action of the water, change its owner." 1

Very similar to this is the case of Indiana v. Kentucky, decided in $1890,{ }^{2}$ which concerned a strip of land known as Green River Island on the north side of the Ohio River. The evidence showed that, when Kentucky became a State in 1792, the river flowed north of the island, and continued to do so after the admission of Indiana to the Union in I8I6. At the time of suit gradual changes in the stream had reduced the northern channel to little more than a ditch, and the island was now claimed by Indiana. Jurisdiction over the land in dispute had always been exercised by Kentucky.

The issue between the parties was really one of historical fact, since the principle of law had been clearly laid down in Missouri v. Kentucky. The Court having come to the conclusion that the river originally flowed north of Green Island it naturally followed that the decision was again in favour of Kentucky:

1 I I Wallace, 4or.

${ }^{2} 136$ U. S., 479. 
"Her dominion and jurisdiction continue as they existed at the time she was admitted into the Union, unaffected by the action of the forces of nature upon the course of the river." 1

And commenting upon the long exercise of jurisdiction by Kentucky the Court observed:

"It is a principle of public law universally recognised that long acquiescence in the possession of territory and in the exercise of dominion and sovereignty over it, is conclusive of the nation's title and rightful authority." 2

The rivers of the Mississippi basin are somewhat erratic in their behaviour, and the next case, that of Nebraska v. Iow'a in $1892,{ }^{3}$ arose out of a sudden and violent change in the course of the Missouri River. By the statutes admitting the two States into the Union their common boundary had been fixed as the middle of the main channel of the stream. "In 1877 ," to quote the language of the Court, "the river above Omaha, which had pursued a course in the nature of an ox-bow, suddenly cut through the neck of the bow and made for itself a new channel." 4

The decision of the case was based upon a distinction known to students of Roman law as the distinction between "avulsion" and " accretion."

"It is settled law," said Mr. Justice Brewer for the whole Court, " that when grants of land border on running water, and the banks are changed by that gradual process known as accretion, the riparian owner's boundary line still remains the stream, although, during the years, by this accretion, the actual area of his possessions may vary. . . . It

1 I 36 U. S., 508.

2 I 36 U. S., 510.

${ }^{3}$ I 43 U. S., 359.

4 I43 U. S., 370. 
is equally well settled, that where a stream, which is a boundary, from any cause suddenly abandons its old and seeks a new bed, such change of channel works no change of boundary; and that the boundary remains as it was, in the centre of the old channel, although no water may be flowing therein. This sudden and rapid change of channel is termed in the law avulsion." 1

The Court was here applying a well-established principle which writers on international law have borrowed from the civil law of Rome. The case did not admit of a decree entirely in favour of either party, since both accretion and avulsion had contributed to the changes in the channel of the Missouri River.

"The only thing which distinguishes this river from other streams in the matter of accretion is in the rapidity of the change caused by the velocity of the current; and this in itself, in the very nature of things, works no change in the principles underlying the rule of law in respect thereto. . . . The boundary therefore between Iowa and Nebraska is a varying line so. far as affected by these changes of diminution and accretion in the mere washing of the waters of the stream." 2

Having laid down the principles of law applicable to the case, the Court declined to make any decree, and suggested to the parties that the line might now be fixed by agreement. This was accordingly done, and a few months later the agreed line was incorporated in a decree of the Court. ${ }^{3}$

The case of Iowa v. Illinois $(1893)^{4}$ turned upon a comparatively small point. The boundary between the two States was "the middle of the Mississippi," a line

1 I 43 U. S., 360-I.

2 I 43 U. S., 369-70.

3 I45 U. S., 519.

4147 U. S., I. 
inherited from the Franco-British treaty of 1763 . The river was spanned by a bridge between the town of Hamilton in Iowa and the town of Keokuk in Illinois, and the question was to what point in the bridge the taxing powers of each State extended. Iowa claimed that the mathematical centre of the river was the true boundary, while Illinois argued for the centre of the main navigable channel. The decree of the Court was given in favour of Illinois, a decision supported by the consent of writers on international law and clearly in accordance with practical convenience. As the Court remarked: "The interest of each State in the navigation of the river admits of no other line."

In the same year was decided the case of Virginia v. Tennessee, ${ }^{1}$ an ancient dispute as to the true location of a surveyor's line. Virginia claimed that the existing line was from two to eight miles too far north of the latitude of $36^{\circ} 30^{\prime}$, which was the line fixed by the English charters. Tennessee contended that the existing line had been fixed by joint agreement in 1803 and acted upon ever since. Although the Constitution (Art. I, Sec. IO) forbids the States to enter into " any agreement or compact " without the consent of Congress, counsel for Tennessee argued that this prohibition was only intended to apply to agreements which might affect the political balance of power in the Union or the supremacy of the United States. It would be manifestly absurd that the States should be debarred from the convenience of direct negotiation upon minor matters. In any event, so it was urged, the consent of Congress in this particular case might fairly be inferred from conduct.

These arguments found favour with the Court, which accordingly decided in favour of the existing line, as claimed by Tennessee. Subsequent proceedings carried 1148 U. S., 503. 
the case on for another ten years, the report of the boundary commissioners being finally confirmed by the Court in $1903 .{ }^{1}$

The case of the United States v. Texas, which was finally decided in $1896,{ }^{2}$ is more important with regard to its subject-matter than most of the boundary cases, for the territory in question amounted to more than a million and a half acres. The demurrer of Texas to the jurisdiction was overruled in $1892,{ }^{3}$ but four years elapsed before the case came on for final hearing. The controversy is extremely complicated, involving as it does the consideration of numerous treaties together with the examination of maps, surveys, and other geographical evidence. So far as the facts can be shortly stated, they are as follows:

Texas separated from Mexico in 1836 and was admitted to the Union in 1845 . Its frontier was therefore determined by the earlier treaties between the United States on the one hand and Spain or Mexico on the other. Of these the most important is the Spanish-American treaty of 1819 , which fixed the frontier as follows:

"The boundary line between the two countries west of the Mississippi, shall begin on the Gulf of Mexico at the mouth of the River Sabine, in the sea, continuing north, along the western bank of that river to the $3^{2 n d}$ degree of latitude; thence by a line due north to the degree of latitude where it strikes the Rio Roxo of Natchitoches, or Red River; then following the course of the Rio Roxo, westward, to the degree of longitude IOO west from London and 23 from Washington; then, crossing the said Red River, and running thence by a line due north to the River Arkansas; thence, following the course of the southern bank of the Arkansas to its source in lati-

1190 U. S., 64.

${ }^{3} 143$ U. S., 621. Ante, p. 29.

${ }^{2}$ I 62 U. S., I. 
tude 42 north; and thence, by that parallel of latitude, to the South Sea. The whole being as laid down in Melish's map of the United States, published at Philadelphia, improved to the first of January, I8r8.

This line was repeated in the treaty with Mexico of 1828 , and in an act passed by the Republic of Texas in 1836 . Texas was admitted to the Union by resolution of Congress in I845, and by Act of Congress in 1850 the borders of Texas were defined as commencing "at the point at which the meridian of one hundred degrees west from Greenwich is intersected by the parallel of thirtysix degrees thirty minutes north latitude."

As the contracting parties were dealing for the most part with a very unsettled and imperfectly surveyed country, it is not unnatural that disputes arose as to the interpretation of these documents. The first question arose as to the identity of the "Red River." Texas contended that the treaty line followed the stream marked as the "North Fork" on the accompanying sketch, while the United States claimed that the southern branch, otherwise known as the "Prairie Dog Town Fork," was the true " Red River." The words of the treaty, " following the course of the Rio Roxo, westward," certainly favoured the Federal argument. To decide this point an immense amount of geographical evidence was investigated by the Court, every available map and book being carefully examined. In the result the Court upheld the claim of the United States.

A further question arose as to the one hundredth meridian. On Melish's very imperfect map this was admittedly misplaced more than a hundred.miles too far to the east. Texas contended that, since the map had been expressly made a part of the treaty, the parties were bound by the meridian as Melish had marked it, irrespec- 


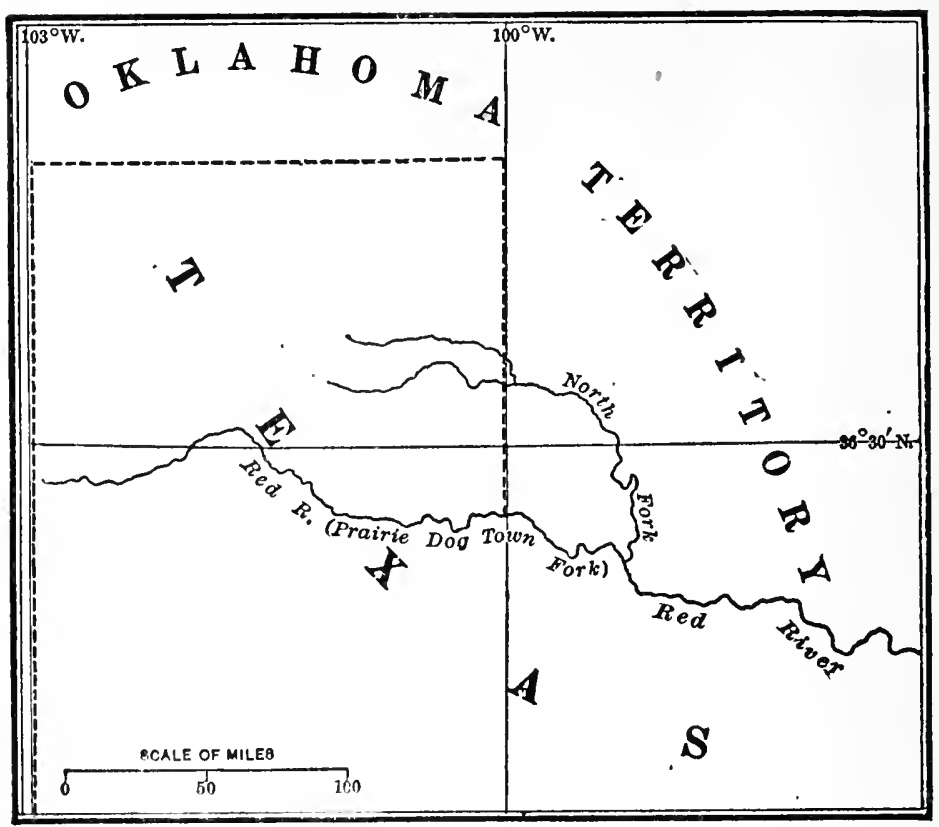

tive of its astronomical correctness. Upon this ingenious argument the Court remarked :

“Melish's map of I8I8 was taken as a general basis for the adjustment of boundaries, but the rights of the two nations were made subject to the location of the lines, with more precision, at a subsequent time, by commissioners and surveyors appointed by the respective governments. So far as is disclosed by the diplomatic correspondence that preceded the treaty, the negotiators assumed for the purposes of a settlement of their controversy that Melish's map was in the main correct. But they did not and could not know that it was accurate in all respects. . . . It was to be fixed with more precision, and designated with more exactness by representatives of the two nations." 1

1 I62 U. S., 38. 
And the Court further pointed out that the reference in the Act of Congress of 1850 was obviously to the true meridian. Texas herself, in fixing the limits of her counties, had also repeatedly acted upon the true line. The case therefore resulted in a decree in favour of the United States.

The unsuccessful attempt of Texas to maintain a treaty line founded upon a blunder may be contrasted with a similar, but little known case in Europe. By the Treaty of the Pyrenees in 1659 Spain ceded to France "thirty-three villages" of the Cerdagne Valley in the eastern Pyrenees. It was afterwards discovered that one village, called Llivia, was legally entitled to be called a "town." Spain thereupon claimed that Llivia was not included in the cession, and this claim was admitted, so that the place remains to this day as an island of Spanish territory in the soil of France.

The case of Missouri v. Nebraska (1904) ${ }^{1}$ needs no more than a passing notice, since the principle of law governing its decision had been already well settled. On

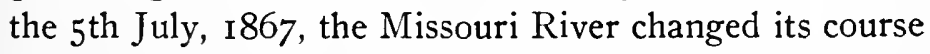
in a few hours and cut a new channel through a narrow neck of land. The old channel soon dried up, thus leaving a piece of Nebraska land attached to the Missouri shore. This being a clear case of "avulsion," the Court had no difficulty in deciding that the title of Nebraska to the land was unaffected by the diversion in the course of the river.

The next case to be considered, that of Louisiana v. Mississippi in $1906,{ }^{2}$ is of more general international interest, because it involves a dispute as to rights in territorial waters of the sea. A reference to the map will show that at the Gulf of Mexico the two States are separated by an arm of the sea called Mississippi Sound. The

1 I96 U. S., 23.

2202 U. S., I and 50. 
conflict arose through the claim of each State to regulate the oyster fisheries in these waters. Matters had in fact gone so far that each party had organised armed patrols to enforce its jurisdiction, so it is probable that the judicial settlement of the controversy prevented a certain amount of bloodshed.

The history of the boundaries begins with the treaty of $17 \mathrm{I} 6$ between Great Britain, France, and Spain, and was followed by the Court through all the various transactions affecting the Louisiana Territory down to the admission of the two States to the Union. It is unnecessary here to examine each of the treaties in detail, since in each the disputed boundary is defined in substantially the same terms. We may begin with the Act of Congress of $\mathrm{I} 8 \mathrm{II}$, passed to enable Louisiana to enter the Union, which thus defines the line:

“. . . along the middle of the said river [Iberville] and Lakes Maurepas and Pontchartrain, to the Gulf of Mexico; thence, bounded by the said Gulf, to the place of beginning: including all islands within three leagues of the coast.

Louisiana was admitted a State by Act of Congress in the next year, and the Act endowed her with additional territory to the north of the lakes already mentioned

" to the eastern mouth of the Pearl River; thence up the eastern branch of the Pearl River to the 3ist degree of north latitude; . . ."

When Mississippi was admitted to the Union in I8I7 the Act of Congress defined her territory as

"including all the islands within six leagues of the shore, to the most eastern junction of Pearl River and Lake Borgne." 


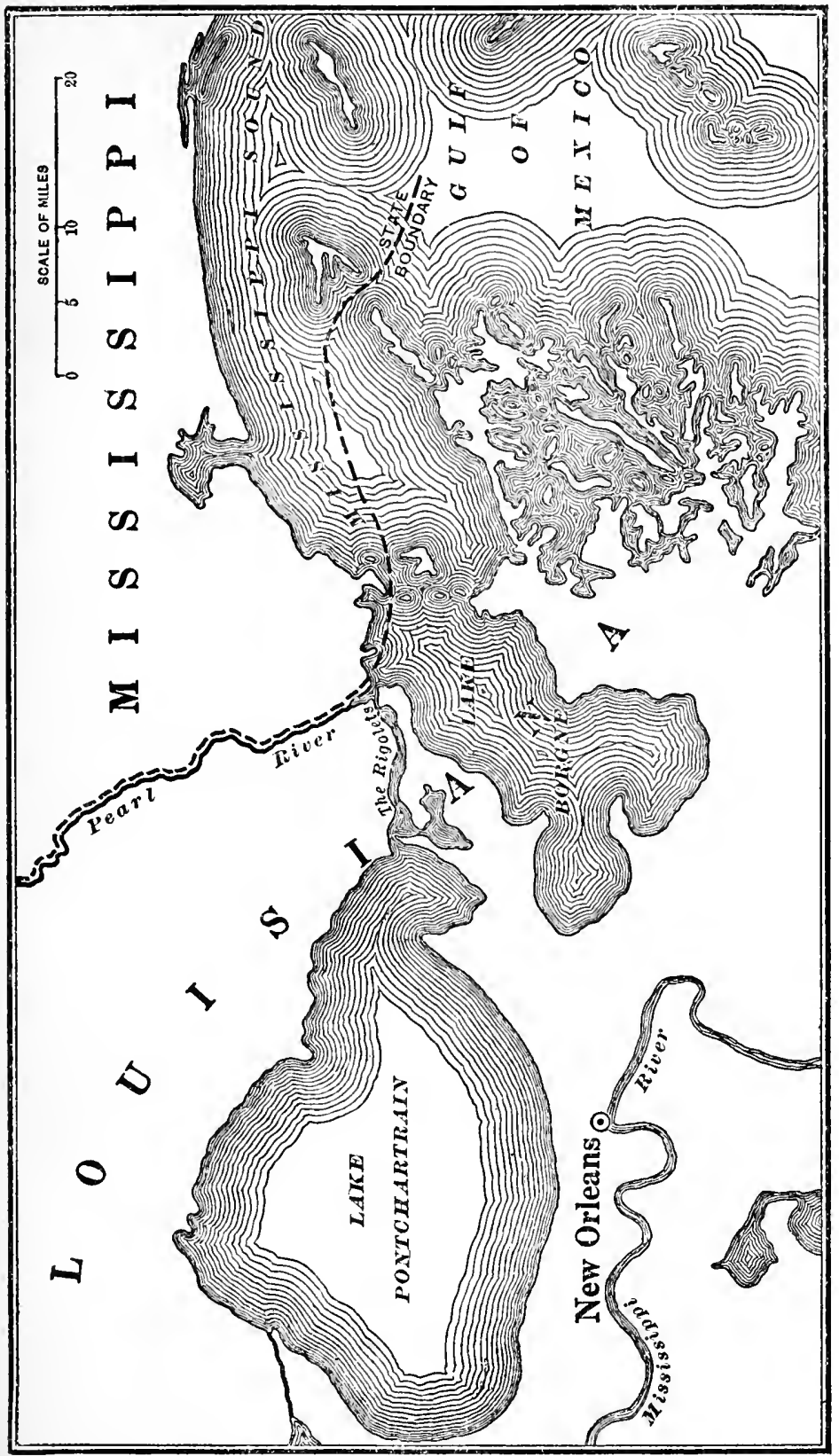

P. 4345

D 
A glance at the map will show at once that these two grants, if read literally, are conflicting, since there are certain islands which lie both within three leagues of the Louisiana mainland and within six leagues of Mississippi. Such a conflict of language, if it existed, could only be resolved in favour of Louisiana as the earlier of the two grantees, since Congress has no power to diminish the territory of a State without the State's consent. Accordingly the Court ruled that the words in the Mississippi Act must be read as applying only to the chain of alluvial islands lying parallel to the Mississippi shore, and adjudged to Louisiana all the islands bordering her own mainland and south of the main channel of the Sound. Furthermore, as counsel for Louisiana pointed out, and the Court agreed:

"Louisiana's title to the disputed territory is confirmed by prescription, usucaption, acquiescence, and specific acknowledgment by the State of Mississippi. . . The disputed territory has always been subject to the sovereignty of Louisiana, and has yielded taxes to her exclusively according to the assessments laid by her officers. . . . The State of Mississippi has recognised the disputed territory as being the property of the State of Louisiana, and her present boundary pretension is but a matter of recent creation after long years of recognition of, and acquiescence in, Louisiana's ownership and sovereignty. It was only after the oyster fishermen of Mississippi by their wasteful system of fishing had either fished up or destroyed all of the Mississippi oysters of any value that these fishermen began to invade Louisiana waters in search of them. Until recent years the Louisiana fisheries were open to all, but are now closed to all except her citizens. It was the exercise of this right that incurred Mississippi's displeasure and brought about this suit." 1

1202 U. S., 26. 
The Court further held, following a decision of Lord Stowell in the English Prize Court, that alluvial islands are appendages of the shores from which they are formed.

Mississippi's claim to the southern group of islands was thus decisively rejected by an unanimous Court. It remained to lay down the rule for fixing the boundary in the water area. The Court decided this upon a principle known to writers on international law as the doctrine of the thalweg or "valley way," which means that the middle of the main navigable channel is to be taken as the boundary. The Court had already applied this doctrine to the case of an inland river boundary in Iowa v. Illinois, and now laid down, in the words of Chief Justice Fuller,

"that, on occasion, the principle of the thalweg is applicable, in respect of water boundaries, to sounds, bays, straits, gulfs, estuaries, and other arms of the sea." 1

It is obvious that this doctrine can have no application to the open sea or to enclosed waters that are navigable over their whole area. Counsel for Mississippi therefore maintained that in this case it did not apply beyond the point where the Rigolets channel entered Lake Borgne, which they argued to be open sea forming part of the Gulf of Mexico. But in point of fact the bay consists of comparatively shallow water except in the main channel, and the Court therefore held that the doctrine of the thalweg applied.

The judgment of the Court accordingly went in favour of Louisiana, and Mississippi was restrained by injunction "from disputing the sovereignty and ownership of the State of Louisiana in the land and water territory south and west of said boundary line as laid down on the

1202 U. S., 50. 
foregoing map." It may be added that the usual practice of the Court in these boundary cases was to make each party bear its own costs and share the costs of any survey that might be necessary. But in this case, as Mississippi was clearly a wrongdoer, she was ordered to pay the costs of the suit. ${ }^{1}$

Washington v. Oregon (I908) ${ }^{2}$ is another case raising a question of boundaries in tidal waters. The definition of the boundary is contained in the Act of Congress of I859, admitting Oregon to the Union:

"Beginning one marine league at sea due west from the point where the forty-second parallel of north latitude intersects the same; thence northerly, at the same distance from the line of the coast, lying west and opposite the State, including all islands within the jurisdiction of the United States, to a point due west and opposite the middle of the north ship channel of the Columbia River; thence, easterly to and up the middle channel of said river, and, where it is divided by islands, up the middle of the widest channel thereof, to a point near Fort Walla Walla."

The Act of I 889 admitting the State of Washington was in substantially the same terms.

In 1859 the river had two main channels, both used by ships, and Congress fixed the boundary in the north one. In the course of time the north channel gradually became unnavigable, and commerce entered the Columbia River by the south channel only. Washington now argued that the boundary between the two States had likewise shifted to the south channel, relying on the doctrine of the thalweg as laid down in the case of Louisiana v. Mississippi. But in this case the application of the doctrine was

1202 U. S., 59.

221 U. S., 127. 
qualified by the fact that Congress had expressly defined the boundary as lying in the north channel.

"The Courts," said Mr. Justice Brewer, "have no power to change the boundary thus prescribed and establish it at the middle of some other channel. That remains the boundary, although some other channel may in the course of time become so far superior as to be practically the only channel for vessels going in and out of the river. . . The boundary between the two States is the centre of the north channel, changed only as it may be from time to time through the processes of accretion." 1

In the next year Washington applied for a rehearing of the case, and attempted to persuade the Supreme Court that it had taken a wrong view of the facts. ${ }^{2}$ The Court, however, saw no reason to alter its original opinion, and concluded the case with a suggestion to the parties that they were now in a position to settle their differences by agreement.

Missouri v. Kansas (1908) ${ }^{3}$ is another of the "midchannel " cases, but one of minor practical importance, a small island in the Missouri River near Kansas City being the only territory in dispute. By gradual erosion of the banks the main channel of the stream had come to flow east of the island. The Court held that the boundary followed the main channel in such a case, and the island was consequently awarded to Kansas. The case illustrates the effect of "accretion" as distinguished from "avulsion."

A somewhat complicated case is that of Maryland v. West Virginia (I9ro), ${ }^{4}$ in which two distinct issues were presented. One question arose upon the correct point of

12 I I U. S., $135-6$.

2214 U. S., 205.
${ }^{3} 213$ U. S., 78.

4217 U. S., I and 577. 
origin for a surveyor's line, and the other question was whether the boundary on the right bank of the Potomac River should be reckoned from high or low water mark. With regard to the first question, it was agreed that the line in question should start from a point described in an English charter of 1632 as "the first fountain of the river Potomac," and thence due north to the southern border of Pennsylvania. The parties differed as to which of two mountain streams was to be regarded as the source of the Potomac, and the difference involved a strip of land about thirty-seven miles long by a mile and a quarter wide. The controversy was of ancient standing, and in I 746 a decree of the King in Council had fixed the point in favour of Virginia, predecessor in title to West Virginia, and it had been marked by a monument called the "Fairfax Stone." From that point a line had been run by a surveyor named Deakins in I788. Maryland had protested then and often afterwards against the correctness of this survey, but in practice the Deakins line had always been acted upon by the inhabitants, and had even been recognised in Maryland grants. Knowing the importance which the Court always attached to long possession, the reader will easily gather from these facts that the decision on this point was bound to be in favour of West Virginia.

With regard to the other question, the charter granted to Lord Baltimore in 1632 gave him ownership of the Potomac "to the farther bank of the said river," and the only doubt that could arise was whether this extended to high or only to low water mark. Here again the argument from possession and from the conduct of the parties was decisive of the matter. The title of West Virginia was derived from her parent State of Virginia. From the earliest times Virginia had treated the soil down to low water mark as her own, and a compact 
with Maryland in I785 had expressly recognised her right of constructing "wharves and other improvements" on the shore. Upon the whole case a decree was accordingly made in favour of West Virginia, with the usual provisions for a detailed survey of the boundaries, the costs being shared equally by the parties. ${ }^{1}$

The reader will recollect that in the case of Alabama v. Georgia $(1859)^{2}$ the Court decided that the word "bank" gave a boundary to high water mark. The contrary decision in the later case really rested upon the argument from long possession.

The case of North Carolina v. Tennessee (I9I4) ${ }^{3}$ was a dispute concerning one of the very few boundaries in the United States which follow watershed lines, but its details are of little interest to any except surveyors. The controversy dated from Revolutionary times, and a compromise between the two States in I82 I had fixed the line in the manner now claimed by North Carolina. Tennessee had never disputed this line until I882, and the present suit arose out of her attempt to grant part of the land in question in 1892. The decision of the Court, as might be expected, was in favour of ratifying the conpromise line of I82I, and commissioners were appointed to mark it in a permanent manner. The report of the commissioners was confirmed in $1916 .{ }^{4}$

The vagaries of the Mississippi River were responsible for the case of Arkansas v. Tennessee, which came before the Supreme Court in 1918.5 What happened is thus described by the Court :

“ On March 7, 1876, the river suddenly and with great violence, within about thirty hours, made for itself a new channel directly across the neck opposite
1217 U. S., 585.
2 Ante, p. 37.
3235 U. S., I.
4240 U. S., 652.
${ }^{5} 246$ U. S., I 58. 
the apex of Dean's Island, so that the old channel round the bend of the elbow (a distance of fifteen to twenty miles) was abandoned by the current, and although it remained for a few years covered with dead water it was no longer navigable except in times of high water for small boats, and this continued only for a short time, since the old bed immediately began to fill with sand, sediment, and alluvial deposits. In the course of time it became dry land suitable for cultivation and to a considerable extent covered with timber." 1

As we have already seen, the treaty of $176_{3}$, which governs all the later documents, made "the middle of the River Mississippi" the boundary between the British and the French possessions. That being so, it would appear that the case was clearly one of " avulsion," but counsel for Tennessee attempted to avoid a decision on this ground by putting forward a theory which they called the " doctrine of submergence and reappearance." Their claim was that during some fifty years the river had by gradual erosion been eating up Tennessee territory, which was only restored by the sudden diversion of the stream in 1876 . This doctrine was to be found in old law books with reference to cases where the sea had engulfed a man's land and subsequently receded, leaving it bare." But the Court declined to extend the principle to the gradual erosion caused by a stream, and the title of Arkansas to the land in question was accordingly held to be unaffected by the "avulsion" of 1876 .

With the case of Arkansas v. Tennessee we come to the last of the boundary disputes that have up to the time of writing been brought for decision to the Supreme Court. Considering them as a whole the most noticeable feature

1246 U. S., 162.

2 It has also been applied in Indian cases, where a river returns to its proper bed and thus restores submerged land. 
of the series is the importance which the Court always attaches to the doctrine that, as the common phrase goes, "possession is nine points of the law." No fixed period of prescription has been laid down, but in every case where there has been uninterrupted possession for any considerable time the judgment of the Court has been given in favour of the possessor.

In the second place it is to be observed that the Court treats every question of boundary as a question of legal title pure and simple. It does not feel that it is entitled to consider what may be called the diplomatic or political aspects of any controversy. Nor under the American Constitution would any other than the strictly legal method be possible. All boundaries in the United States depend upon legal documents of some kind, either English charters, or treaties with foreign powers, or Acts of Congress and the State Legislatures. Furthermore the States are forbidden to employ among themselves either wat or diplomacy or economic coercion, so no questions of strategic or economic frontiers can possibly arise. The Constitution contains no provisions for settling boundaries in accordance with the wishes of the people immediately affected, but it does provide (Art. IV, Sec. 3) that no State shall be deprived of any territory whatsoever without its own consent. The Court therefore, in determining boundary questions, is guided in the first instance by the written Constitution, and secondly by the treaties and other legal acts applicable to the particular case. If these are not sufficiently explicit to conclude the matter, recourse is had to the principles of the English Common Law or to any rules that find general acceptance among the leading writers on international law. The fact that the English Common Law is the foundation of American jurisprudence has supplied the Court with a coherent body of doctrine which enables it to render a 
series of judgments resting upon a uniform basis of principle. $^{1}$

These circumstances must be carefully borne in mind when it is desired to create a Court of the Nations with functions in any way resembling those of the Supreme Court of the United States. If we are to establish any kind of permanent tribunal, as distinguished from occasional arbitration commissions, we must provide it, in outline at least, with a consistent body of rules upon which to work. Nations can hardly be expected to commit their destinies to the arbitrament of a small group of men who are guided by nothing better than their own discretion. ${ }^{2}$

But the real difficulty will arise when the Court is called upon to solve boundary questions which have their root in deep-seated political conflicts. It is comparatively easy to decide a dispute which turns upon the construction of a document or the legal effect of deviations in the course of a river. But it is manifest that the rules laid down in such cases do not help us to determine, for example, where the boundaries shall be drawn between Italy and Serbia on the Adriatic coast. All courts presuppose laws, or at least some commonly accepted notions of justice, and if these grave political controversies are to be brought within the range of judicial settlement, it is necessary that we should agree beforehand upon some leading principles by which they are to be decided. It is clear that the doctrine of long possession so strongly favoured by the Supreme Court will not be of itself sufficient. In this present year, I9I9, the civilised world is busily engaged in breaking up arrangements which have centuries of established title to support them. The fact

${ }^{1}$ This has been repeatedly pointed out by the Court itself : "The language of the Constitution, as has been well said, could not be understood without reference to the Common Law."United States v. Wong Kim Ark ( 169 U. S., 654), per Mr. Justice Gray.

2 Upon this point see also Chapter VII. 
that an injustice has lasted a long time is an insufficient reason for deciding that it must continue for ever.

It is not within the province of this essay to lay down rules for the settlement of such questions. Present indications point to the adoption in some form or other of the doctrine of the plébiscite, though this too has its difficulties, especially in dealing with mixed populations and undeveloped races. But it is essential to understand that unless some common principles of decision are agreed upon by the civilised world these grave political controversies cannot be judicially settled at all. 


\section{CHAPTER IV}

\section{THE RECOVERY OF STATE DEBTS}

When in 1793 the Supreme Court decided in Chisholm v. Georgia ${ }^{1}$ that a State could be sued by a citizen of another State for the recovery of a debt due to him a wave of indignation swept through the Union at the affront thus offered to the dignity of a "sovereign" power. Georgia utterly refused to comply with the judgment, and the Eleventh Amendment was passed to prevent a repetition of the outrage. To those States which took a low view of their moral obligations the Amendment proved a charter of liberty, and several were accordingly relieved of considerable financial embarrassment. Various attempts to circumvent the Amendment were defeated by the Supreme Court, which refused to allow a State to be sued except in cases where the creditor had unreservedly assigned his interest to another State. ${ }^{2}$

It follows that a State can only be sued by another State, or by the United States, or by a foreign State. For various reasons inter-State suits arising out of money matters are not common. In the first place, the Constitution (Art. I, Sec. IO) forbids the States to enter into binding agreements with one another without the consent of Congress. Secondly, experience has taught the people to look with great suspicion upon the readiness of their legislatures to incur indebtedness, and most of the State Constitutions now contain stringent restrictions upon the

12 Dallas, 4I9. See p. 9, ante.

2 See p. 9, ante. 
power of the legislature to pledge the credit of the State. Not only are the purposes for which debt may be incurred very strictly defined, but the Constitution usually requires that the borrowing act shall provide for a sinking fund to pay off the debt in a few years. ${ }^{1}$

A few cases, however, have arisen in which actions for debt have been maintained against a State. In Unitcd States v. North Carolina (1890) ${ }^{2}$ the Federal Government sued for the interest due upon I 47 thousand-dollar bonds of the State after the bonds had become payable. The State had belatedly paid up the principal sum due, together with interest to the date of maturity, so the only question remaining was whether interest could be claimed for the period between maturity and actual payment. As a matter of law between private individuals there could be no doubt upon the matter. If a man will not pay his debts when they are due, he must be prepared to pay interest for such time as he chooses to remain in arrear. The Court, however, held that where a State was the debtor the ordinary doctrine did not apply. Mr. Justice Gray, speaking for a majority of the Court, considered that the dignity of a sovereign power was involved:

"Interest, when not stipulated for by contract or authorised by statute, is allowed by the Courts as damages for the detention of money or of property, or as compensation, to which the defendant is entitled; and, as has been settled on grounds of public convenience, is not to be awarded against a sovereign government, unless its consent to pay interest has been manifested by an act of its legislature, or by a lawful contract of its executive officers." 3

1 The English reader will find a characteristic example of these provisions in the Constitution of Oklahoma, which is printed in Bryce's American Commonicalth, vol. i, pp. 735-6.

2136 U. S., 211 .

${ }^{3}$ I 36 U. S., 216. 
The bonds in question were made payable in New York, and by the law of that State interest is payable on bonds after maturity. North Carolina had, however, made no such provision, and the Court held that the case was to be governed by her laws:

"Contracts are to be governed, as to their nature, their validity, and their interpretation, by the law of the place where they are made, unless the contracting parties appear to have had some other place in view." 1

Judgment was accordingly given against the claim of the United States.

Unitcd States v. Michigan ( I903) ${ }^{2}$ was a case where the United States claimed to be repaid the balance of certain moneys advanced to the State for the building of the St. Mary's River Canal at the lower end of Lake Superior. The Federal Government had granted to the State 750,000 acres of land, which were to be sold to provide a building fund. Out of this fund the canal was built, without any expense to Michigan, and the costs of operation were met by the levy of tolls. When the work was completed a considerable sum remained over, and this surplus Michigan proposed to retain for her own use. The United States contended that the whole fund was impressed with a trust for the specific purpose of building the canal, and that the State was therefore bound to repay the surplus remaining after the canal had been built. The decision of the case necessarily turned upon the wording and intention of the relevant statutes. For our purpose it is sufficient to summarise the result in the words of Mr. Justice Peckham:

"That the parties supposed the cost would be borne by the United States is proved by an examina1 Ibid., 222. 2190 U. S., 3ॅ9. 
tion of the statutes, and if it be a fact, it goes far to show that the State was in this matter acting in effect and substance as an agent, or, in other words, as a trustee for the United States, and that the transaction was not to be a source of profit to the State, by reason of getting more from the United States than it would cost to build the canal." 1

The principle underlying the decision was thus defined:

"Where words are ambiguous, legislative grants must be interpreted most strongly against the grantee and for the Government, and are not to be extended by implication in favour of the grantee beyond the natural and obvious meaning of the words employed. Any ambiguity must operate against the grantee and in favour of the public." 2

The facts in the case of South Dakota v. North Carolina (1904) ${ }^{3}$ have already been briefly noticed. The case has two points of interest, neither of which belongs properly to the present chapter. In the first place it was claimed that the jurisdiction of the Court was ousted by the Eleventh Amendment, and this point, as we have seen, was decided in favour of the plaintiff. The other question which the Court had to consider was by what means it could make its judgment effective. To this we shall return later. Upon the merits of the controversy North Carolina had no defence. Payment of both principal and interest upon the bonds was long overdue, and the debt had in effect been repudiated by the State. The question of jurisdiction having been decided in favour of the plaintiff, judgment for the sum due necessarily followed.

It has already been mentioned that in 1855 Congress established a "Court of Claims" for the judicial settlement of contractual and similar claims against the Federal authorities. Prior to this Act the only remedy of an

1190 U. S., 397.

${ }^{3}$ I92 U. S., 286. See p. 2I, ante, and p. 99, post.

2 Ibid., 401. 
aggrieved citizen was by the clumsy and unsatisfactory method of a petition to Congress for redress of his grievances. In I887 the Supreme Court held in United States v. Louisiana ${ }^{1}$ that the States might avail themselves of this tribunal, with a right of appeal by either party to the Supreme Court. It will be convenient to group together here the few cases in which States have availed themselves of this right.

The facts of United States v. Louisiana, which reached a final decision in $1888,{ }^{2}$ are in themselves of little interest. The claim of the State was for sums due to her under certain Acts of Congress, which had allocated part of the proceeds of the sale of Federal lands to be applied for the carrying out of public improvements within the State territory. This liability was admitted by the United States, but it was claimed to set off against the amount of this debt certain unpaid taxes due from citizens of Louisiana to the Federal Treasury. The taxes, however, were due from the citizens individually, and not from the State as such. The Court therefore held that these sums could not be set off against the money due from the United States to Louisiana.

More successful was the clain of the United States to set off the amounts due upon certain State bonds. The Federal Government held a large number of Louisiana bonds, upon which the interest had not been paid. Since this was a liability of the State itself, as distinguished from its citizens, the Court held that it must be set off against the debt due to Louisiana from the United States.

In I893 a similar claim was brought by the State of Indiana, ${ }^{3}$ based upon certain Acts of Congress which

1 I 23 U. S., 32.

2 I27 U. S., 182. The name of the United States appears first in the title, since the Federal Government was appealing from the decision of the Court of Claims.

${ }^{3}$ I 48 U. S., I 48. 
directed the sales of public lands to be applied in the construction of national roads through Indiana and other States. The case requires only the briefest notice, for the Court found that the cost of constructing the roads in Indiana greatly exceeded the sums arising out of the sale of lands. The claim of the State subsequently failed.

The case of United States v. New York ( 1896$)^{1}$ may be compared with the case of United States v. North Carolina, already noticed. The claim of the State was based upon an Act of Congress of I86I, which directed the Treasury to reimburse the States the expenses they might incur in raising contingents for the Union armies in the Civil War. New York had raised the money by borrowing, and the main question in the case was whether she was entitled to be repaid the interest on the sums borrowed as part of her "costs, charges, and expenses properly incurred" under the Act of I86I. The Court distinguished the North Carolina case, and upheld the claim of the State.

"It could not have borrowed money," said Mr. Justice Harlan, " any more than the General Government could have borrowed money, without stipulating to pay such interest as was customary in the commercial world. Congress did not expect that any State would decline to borrow and await the collection of money raised by taxation before it moved to the support of the nation." 2

South Carolina v. United States $(1905)^{3}$ is a somewhat peculiar case. By various statutes the State took over the whole business of the sale of liquor within its borders, and prohibited the sale of liquor except by "dispensers," who were State officials without any financial interest in the profits of the business. But the United States also was interested in regulating the trade for

$$
\begin{aligned}
& 1 \text { 160 U. S., } 598 . \quad{ }^{2} \text { 160 U. S.. } 621 . \quad{ }^{3} 199 \text { U. S., } 437 . \\
& \text { P. } 4345
\end{aligned}
$$


revenue purposes, and Federal statutes imposed a licence tax upon all retail dealers in wine or spirits. For some years the State paid the Federal tax for its dispensers, but in I9Or a protest was entered, and this developed into a suit in the Court of Claims for the return of the sums paid.

The question was of some importance. Under the American Constitution the powers both of the National and of the State Governments are sharply marked out, and the Supreme Court had long ago held that neither of these could, under colour of taxation, be permitted to interfere with the legitimate activities of the other. Thus in McCulloch v. Maryland (1819) ${ }^{1}$ the Court had disallowed the attempt of a State to tax the operations of a national bank, and in The Collector v. Day (I870) ${ }^{2}$ it had ruled that Congress could not tax the salary of a State judge. The present case, however, appeared to the Court to rest upon a different principle. Admitting that Congress could not lawfully tax the governmental activitives of a State, the Court nevertheless held that in assuming a monopoly of the liquor trade South Carolina had so far discarded her political character and had accepted the status of an ordinary trader. The Constitution, in the opinion of the Court, must be adapted to meet conditions that could never have been present to the minds of its framers. Otherwise the growing tendency of States to engage in business activities might result in rendering ineffective the greater part of Federal taxation. A majority of the Court accordingly held that the State dispensers were liable to the tax. Three judges dissented from this decision on the ground that

"By the ruling and the reasoning sustaining it the ancient landmarks are obliterated and the distinct powers belonging to both the National and State

14 Wheaton, 316.

2 II Wallace, in 3. 
Governments are reciprocally placed the one at the mercy of the other, so as to give to each the potency of destroying the other." ${ }^{1}$

The most important of all the State debt cases is that of Virginia v. West Virginia, which was entered in the Supreme Court in 1906." and has been reappearing at frequent intervals up to IgI8. It has its roots in the great conflict of the Civil Var, and until lately threatened to confront the Supreme Court with the problem, so long evaded, of how a final judgment is to be enforced.

The circumstances leading up to the formation of West Virginia have already been briefly noticed, and we have seen how in the first lawsuit between the two States the political ownership of two disputed counties was adjudged to West Virginia. The present claim of Virginia arose out of the fact that her assent to the formation of the new State was obtained only upon the distinct undertaking of the latter to shoulder a fair share of Virginia's pre-war debt. The terms of the undertaking were thus expressed in the ninth ordinance of the Wheeling Convention of I 86 I :

"The new State shall take upon itself a just proportion of the public debt of the Commonwealth of Virginia, prior to the first day of January, I86I, to be ascertained by charging to it all State expenditures within the limits thereof, and a just proportion of the ordinary expenses of the State government, since any part of said debt was contracted; and deducting therefrom the monies paid into the treasury of the Commonwealth from the counties included within the said new State during the same period."

The obligation thus undertaken was reaffirmed in the eighth article of the West Virginian Constitution:

1 I99 U. S., 464.

2206 U. S., 290. 
"An equitable proportion of the public debt of the Commonwealth of Virginia, prior to the first day of January, in the year one thousand eight hundred and sixty-one, shall be assumed by this State; and the legislature shall ascertain the same as soon as may be practicable, and provide for the liquidation thereof, by a sinking fund sufficient to pay the accruing interest, and redeem the principal within thirty-four years."

For more than forty years Virginia did all in her power by friendly negotiation to induce the younger State to settle the obligation thus solemnly contracted. ${ }^{1}$ All these efforts proved unavailing, and in Igo6 Virginia took the matter to the Supreme Court. In the next year the case was argued upon the question of jurisdiction, and the demurrer of West Virginia to the jurisdiction was, as we have already seen, overruled. In Igo8 the Court appointed a master to settle the form of the account, ${ }^{2}$ giving him wide powers to compel the production of all necessary evidence. The report of the master came before the Court in I9I ${ }^{3},{ }^{3}$ and was strenuously resisted by counsel for West Virginia, but their objections did not prevail. The Court refused at this stage to proceed to a final decree, contenting itself with laying down some guiding principles for the valuation of the debt, to be worked out in detail, if need be, by the master. But a strong hope was expressed that the parties might reach an agreement which would render further litigation needless.

" This case," said Mr. Justice Holmes, " is one that calls for forbearance upon both sides. Great States have a temper superior to that of private

1 See the remarks of the Court upon this point, p. 27, ante.

2200 U. S., 514.

3220 U. S., I. 
litigants, and it is to be hoped that enough has been decided for patriotism, the fraternity of the Union, and mutual consideration to bring it to an end."

The hopes of the Court were destined to disappointment. Virginia at once attempted to arrange a conference with the West Virginian authorities, but the Governor of West Virginia failed to respond. Accordingly, in October, I9II, Virginia again appeared before the Supreme Court with a motion praying for a speedy hearing and determination of the case. The Court, always very tender in its dealings with States, refused to hustle West Virginia.

"A State," said Mr. Justice Holmes, " cannot be expected to move with the celerity of a private business man; it is enough if it proceeds, in the language of the English Chancery, with all deliberate speed."

So the case was left to await the meeting of the legislature of West Virginia in ordinary session in January, I9I3. When the legislature met, it did at last appoint a commission to deal with the question, but in the course of a few months Virginia decided that even this new move gave little promise of a settlement. In October, therefore, she again moved the Supreme Court for a speedy decision. ${ }^{3}$ West Virginia thereupon asked for six months more time, which would have meant carrying the case over to the next term, and really delaying the decision by another year; the Court accordingly told her that she must be ready with her answer in five months time.

When the five months had passed West Virginia asked for yet another postponement to enable her to file a " supplemental answer." 4 With a tolerance which would

$$
\begin{array}{llll}
1 & 220 & \text { U. S., } & 36 . \\
2 & 222 & \text { U. S., } & 19-20 .
\end{array}
$$

3231 U. S., 89.

$423+$ U. S., II\%. 
never have been extended to an ordinary litigant ${ }^{\mathbf{1}}$ the Court granted this request, and the case was referred back to the master with directions to have his report ready by October, I9I4. In the next year, all methods of delaying the decision being now exhausted, the case at last came on for final hearing on the questions raised by the master's report. ${ }^{2}$

The Court had already held in I9I I that West Virginia was bound by contract to pay whatever should turn out to be the correct sum, and the present proceedings therefore resolved themselves into an argument upon the correctness of the items set forth in the report. One or two points decided are of general interest. West Virginia claimed that certain heavily depreciated stock held by Virginia should be valued at the sum originally paid for it. The Court, however, decided that it must be assessed according to its actual value on the Ist January, I86I. In favour of West Virginia it was held that she was entitled to a proportionate share of the benefit of an arrangement which Virginia had made with her creditors.

A more important point was whether West Virginia should be charged with interest for the long period during which the debt had remained unpaid. The Court, it will be remembered, had already held that a State cannot be charged with interest except by its own consent. That being so, the question became one of the interpretation of the contract between the two States. Although the agreement in this case contained no express provisions relating to interest, the Court held that upon its " fair intendment" the payment of interest was contemplated.

"There is no escape from the conclusion," said Mr. Justice Hughes, " that there was a contract duty on the part of West Virginia to provide for accruing

1 For the remarks of the Court upon this point, see p. 108, post.

2238 U. S., 202. 
interest as a part of the equitable proportion assumed, and that it would be highly inequitable as between the two States that Virginia as to her share should bear interest charges for these fifty years while West Virginia on her part should simply pay a percentage of principal reduced by the credits which have been allowed." 1

Various other questions of accounting having been similarly cleared up the Court finally assessed the indebtedness of West Virginia at the sum of $\$ 12,393,929.50$. The decree further provided that this sum should bear interest at the rate of five per cent. until it was paid. The costs were to be equally divided between the two States. $^{2}$

This decree was pronounced on the I4th June, I9I5, and the subsequent proceedings in the case belong more properly to another chapter. The whole case leaves a somewhat unpleasant impression on the mind of an outside observer. Nothing could be more solemn than the agreement by which West Virginia expressly undertook, as a condition of her independence, to bear a fair share of the pre-war debt of the parent State, and promised that her legislature should ascertain the exact amount "as soon as may be practicable." Yet for forty-three years she took no steps whatever to discharge this solemn obligation. When the matter was brought into the Supreme Court West Virginia first of all denied the jurisdiction of the tribunal, and then interposed every dilatory motion that the ingenuity of her counsel could suggest to postpone a decision of the case upon the merits. The attempts of Virginia to settle the matter in an amicable conference met with no real response, in spite of the fact that this course was suggested on the authority of the Court itself. Finally, she has allowed nearly four

$$
1238 \text { U. S., } 236 .
$$

$$
2238 \text { U. S., } 242 .
$$


years to elapse since the pronouncement of the decree before taking any steps to render it obedience. In the case of a private individual or a commercial company such conduct would doubtless call down a rebuke which the Court is unwilling to administer to a State of the Union. 


\section{CHAPTER V}

\section{CASES OF INJURY BY STATE ACTION}

THERE remain to be considered five cases in which the political action of an American State has been challenged in the Supreme Court as an injury to the rights of its neighbours.

The first of these cases is that of Cherokee Nation v. Georgia (I83I), ${ }^{1}$ which would have raised questions of the highest interest and importance had not the Court, by denying the jurisdiction, prevented an inquiry into the merits of the Indian complaint. This decision rested on the rather narrowly technical ground that the Indian tribes were not "foreign States" within the meaning of the Constitution, but were rather what Marshall described as "wards of the United States." The strong minority which disapproved of this ruling included Mr. Justice Story, a jurist whose fame is second only to that of Marshall in the annals of American jurisprudence, and if the question had arisen forty years later, when the Court felt more sure of its position, it is probable that the jurisdiction would have been entertained. That the sympathies of the whole Court were strongly with the Indians is clear from Marshall's words:

"This bill is brought by the Cherokee nation, praying an injunction to restrain the State of Georgia from the execution of certain laws of that State, which, as is alleged, go directly to annihilate

15 Peters, I. 
the Cherokees, as a political society, and to seize, for the use of Georgia, the lands of the nation which have been assured to them by the United States, in solemn treaties repeatedly made and still in force.

"If courts were permitted to indulge their sympathies, a case better calculated to excite them can scarcely be imagined. A people, once numerous, powerful, and truly independent, found by our ancestors in the quiet and uncontrolled possession of an ample domain, gradually sinking beneath our superior policy, our arts and our arms, have yielded their lands by successive treaties, each of which contains a solemn guarantee of the residue, until they retain no more of their formerly extensive territory than is deemed necessary to their comfortable subsistence. To preserve the remnant the present application is made." 1

Marshall's words are a very fair summary of the treatment actually meted out to the Indians, and since the case went no further, it is needless to examine the complaint iil greater detail. It may, however, be doubted whether Georgia would in any case have obeyed an adverse decision of the Supreme Court in such a matter. We have already scen how she successfully resisted the Chisholm judgment, and in another case ${ }^{2}$ she refused to liberate certain persons imprisoned under a Georgian statute which the Court held to be unconstitutional. The position of the Court in Marshall's time was by no means established, and the doctrine of "State Rights " remained powerful, especially in the Southern States. Georgia acted on the principle that she could deal with the Indians exactly as she pleased, and there is no reason to think that she would have paid any more respect to a judrment of the Supreme Court than she was willing to show

15 Peters, I 5.

2 Horcester v. Georgia (1832), 6 Peters, 515. 
for treaties that pledged the good faith of the United States.

Incidentally it may here be observed that up to the present time no suit by a foreign State against a State of the Union has been prosecuted to judgment in the Supreme Court. In I9I7 the Republic of Cuba entered a claim against North Carolina ${ }^{1}$ upon certain State bonds, the circumstances of the case being similar to those of South Dakota v. North Carolina, which we have already noticed. Cuba, however, obtained leave to withdraw the suit before the case came on for a hearing on the merits.

In 1876 Georgia was again a defendant in the Supreme Court, the plaintiff in this case being South Carolina. ${ }^{2}$ The dispute was one concerning the proper use of the Savannah River, which constitutes the greater part of the boundary between the two States. At the mouth of the river, opposite to the city of Savannah in Georgia, the stream divides, enclosing a long strip of land known as Hutchinson's Island. The northern or South Carolinan channel is known as the Back River, and the southern channel, which flows past the city of Savannah, is called the Front River. In 1787 an agreement, known as the "Treaty of Beaufort," between South Carolina and Georgia declared the navigation of the river to be " equally free to the citizens of both States, and exempt from all duties, tolls, hindrance, interruption, or molestation whatsoever attempted to be enforced by one State on the citizens of the other." This agreement defined the channel of free navigation as running "up the direct course of the main northern channel, along the northern side of Hutchinson's Island," and everything south of the line so defined was declared " to be the exclusive right of the State of Georgia."

In 1874 and 1875 Congress passed acts appropriating ${ }^{1} 242$ U. S., 665.

293 U. S., 4. 
substantial sums "for the improvement of the harbor at Savannah." The improvement took the form of diverting water by a dam from the Back River into the Front River, with the object of increasing the depth of the water at Savannah by fifteen feet. To this South Carolina objected, taking her stand on the agreement of 1787 . The Secretary of War was joined with Georgia as a defendant to the action, since Congress had entrusted to him the execution of the works.

The Court unanimously held that the agreement of I787 was no longer relevant, having been superseded by the Constitution of the United States, to which South Carolina and Georgia had given their assent in I788. Under the Constitution every State delegated some of its rights to the United States, and the rights so delegated included the right "to regulate commerce with foreign nations, and anong the several States." The power to regulate commerce, as the Court observed, had been held to include the control of navigable rivers, and a river may in certain cases be made more navigable by placing obstructions therein. Before the adoption of the Constitution the power to regulate commerce lay with the States, and the works now in question could admittedly have been carried out by the joint authority of the two riparian States. Since each of them by accepting the Constitution had surrendered its rights in the matter to the Federal Government it necessarily followed that the same works could now be carried out by Federal authority.

South Carolina also relied upon the provision of the Constitution (Art. IX, Sec. I) which directs that

" no preference shall be given by any regulation of commerce or revenue to the ports of one State over those of another: nor shall vessels bound to, or from, one State be obliged to enter, clear, or pay duties in another." 
The Court, however, held, relying upon an earlier decision of its own, ${ }^{1}$ that this clause did not prohibit

"acts which may directly benefit the ports of one State, and only incidentally injuriously affect those of another, such as the improvement of rivers and harbours, the erection of lighthouses, and other facilities of commerce."

In other words, provided that the Federal power is exercised in good faith for the good of the community as a whole, the Court will not interfere merely on the ground that certain individuals or sections of the community may suffer incidental loss. The legality of the improvements was therefore affirmed, and the bill of South Carolina dismissed.

We now come to a group of three closely allied cases, to which reference has already been made in discussing the question of jurisdiction. The fundamental issue in each one is the right of a State to protect its citizens, as distinct from its own corporate interests, from injury caused by the action of a neighbouring State. The three decisions are not easily reconcilable, and the conflict between the first case and the two later ones really marks a change of mind in the judges, who were gradually led to accept a broader view of their jurisdiction. The main facts have already been briefly stated, but in this chapter they require a slightly fuller analysis.

The first of the group is Louisiana v. Texas ( 1900$),{ }^{3}$ a dispute which, if it had arisen between independent States, might easily have led to war. Texas by statute had given to her own civil authorities wide powers to make and enforce very drastic quarantine regulations. These powers included the right to detain vessels, per-

${ }^{1}$ Pennsylvania v. Whecling \& Belmont Bridge Co. (1856), 18 Howard, $42 \mathrm{I}$.

293 U. S., I3.

3 I 76 U. S., 1 . 
sons, and property coming into Texas from localities deemed to be infected. In I899, so Louisiana alleged, the Health Officer of Texas took advantage of the occurrence of a single case of yellow fever in New Orleans, in a district several miles from the commercial quarter, to lay an embarso on all inter-State commerce between New Orleans and the State of Texas, and this embargo was enforced by armed guards posted at the frontier. Louisiana complained that the real motive underlying the embargo was the desire, not to protect the public health, but to divert commerce from New Orleans to the port of Galveston in Texas. In proof of this she alleged that commerce entering Galveston direct from the seriously infected ports of Mexico and other countries was treated leniently and only subjected to reasonable regulations. Finally she claimed that the whole action of Texas was really an attempt to regulate inter-State commerce, which is one of the matters reserved under the Constitution to the United States.

The Court, however, refused to entertain the suit. There was considerable difference of opinion among the judges, and some who concurred in the result did so for divergent reasons. The decision was explained in the later case of Missouri v. Illinois on the ground that " the Court did not decline jurisdiction, but exercised it in holding that the facts alleged in the bill did not justify the Court in granting the relief prayed for." 1 The distinction seems a little fine-drawn in view of the statement of Chief Justice Fuller that " if the case stated is not one presenting a controversy between these States, the exercise of original jurisdiction by this Court as against the State of Texas cannot be maintained." "

It is, however, needless to linger over these verbal refinements. The substantial reason for the judgment

1 I 80 U. S., 240.

${ }^{2} 176$ U. S., 19. 
seems to have been that Louisiana could not maintain a suit to protect the people of New Orleans, who were the parties principally affected by the Texan regulations. She was not entitled to act as "parens patriac, trustee, guardian or representative of all her citizens." 1 The majority of the Court also took the view that Texas had not so far adopted or authorized the action of her health officer as to make it her own. Altogether the decision seems to rest upon a narrow and technical reasoning which contrasts strongly with the general tendency of the Court to avoid technicalities and to base its judgments upon broad principles of justice and fair dealing.

The demurrer of Texas having been upheld, the case ended, and no investigation of the merits was possible. The international lawyer will doubtless regret the lost opportunity of an argument upon a matter of fundamental importance in international law, namely, the extent to which a State may manipulate its own municipal laws for the purpose of inflicting injury upon a neighbour. According to the Chief Justice such matters cannot be judicially investigated at all. "Public policy," he said, "forbids the imputation to authorised official action of any other than legitimate motives." " Such an assumption is of course notoriously at variance with known facts, and it is to be hoped that no international court will thus restrict its usefulness with needless fictions.

In the next year the Court was faced in the case of Missouri v. Illinois ${ }^{3}$ with a similar problem, although no question of malice was here involved. These two States are bounded by the Mississippi, and the city of St. Louis stands on the western or Missouri bank of the river fortythree miles below the mouth of the Illinois River, which flows entirely through the territory of Illinois. The dispute arose out of a drainage scheme whereby Illinois
1 I 76 U. S., i 9.
${ }^{2}$ I76 U. S., 18.
3 I80 U. S., 208. 
proposed to divert the sewage of Chicago from Lake Michigan into the Illinois River, from which it would of course flow into the Mississippi above St. Louis. The sewage was to be brought from Chicago to the Illinois River by a specially constructed canal. Missouri contended that this great mass of crude sewage would so pollute the waters of the Mississippi as to render them unfit for ordinary use, and would seriously injure the health of her inhabitants.

As we have already seen, a majority of the judges held in this case that the controversy was one within the jurisdiction of the Court, though Chief Justice Fuller and two of his brethren took the same line as they had taken in the Texas case. For the majority Mr. Justice Shiras observed:

"It must surely be conceded that, if the health and comfort of the inhabitants of a State are threatened, the State is the proper party to represent and defend them. If Missouri were an independent and sovereign State all must admit that she could seek a remedy by negotiation, and, that failing, by force. Diplomatic powers and the right to make war having been surrendered to the general government, it was to be expected that upon the latter would be devolved the duty of providing a remedy, and that remedy, we think, is found in the constitutional provisions we are considering." 1

The jurisdiction having been thus affirmed a long pause ensued, and the case did not come on for argument on the merits until 1906. ${ }^{2}$ The question now became mainly one of fact, and a mass of scientific and other evidence was laid before the Court. The burden of proof lay upon Missouri, who had to establish that the acts of

1 I80 U. S., 24 I.

2200 U. S., 496. 
Illinois were sufficient to create a " nuisance" in the legal sense of the word. This burden she failed to discharge. A slight increase of typhoid fever at St. Louis proved nothing, for there was no corresponding increase along the banks of the Illinois River itself. This river appeared to have been actually improved by the change. The introduction of a large body of fresh water from Lake Michigan transformed it from a sluggish stream into a quick and clear one, to which edible fish had now returned. The waters of the Missouri River appeared to be in fact more polluted than those of the Illinois, which falls into the Mississippi slightly higher up than the mouth of the Missouri. Any inconvenience that St. Louis suffered might, therefore, be easily attributable to the Missouri River, flowing through Missouri territory.

This really disposed of the case, for it could not be argued that the action of Illinois was unlawful except upon the ground of nuisance. Since the rivers were navigable Congress might have undertaken to regulate them, but, as it had not done so, Illinois was free to act in any way that did not violate the rights of her neighbours. Upon the application of Illinois Missouri was ordered to pay the costs of the suit. ${ }^{1}$

In the case of Kansas v. Colorado the question of jurisdiction was decided in $1902,{ }^{2}$ but the final decision upon the merits was not reached until $1907 .^{3}$ The question was one of the respective rights of the parties in the waters of the Arkansas River. This river rises in the Rocky Mountains and drains a basin of about 22,000 square miles in the State of Colorado before it enters Kansas. Much of this area being mountainous the river receives a large additional volume of water in the spring. In Kansas the stream flows through alluvial lands, and urains an area of less than four thousand square miles.

$$
\begin{aligned}
& 1202 \text { U. S., } 600 . \quad{ }^{2} 185 \text { U. S., I25. } \\
& \text { P. } 4345
\end{aligned}{ }^{3} 206 \text { U. S., } 46 .
$$


Owing to the porous nature of the soil most of the rainfall in this area did not reach the river. ${ }^{1}$

Kansas complained that she was being deprived of the natural flow of the water owing to certain extensive irrigation works that were being carried out under the authority of the Colorado legislature, with the result that a large portion of Kansas territory was in danger of becoming a desert. Colorado, after vainly disputing the jurisdiction of the Court, maintained that she was entitled to deal exactly as she pleased with all the waters in her own territory, even if the result should be to cut off the water from Kansas altogether. This was an appeal to sovereign rights. Kansas, on the other hand, took her stand on the English common law rule that all riparian owners have equal rights in the uninterrupted flow of the stream. In other words, she asked the Court to regard the question as one of strictly legal rights between individuals. Furthermore she relied upon the fact that she entered the Union in I86I, whereas Colorado was not admitted until 1876 ; from which it would follow, that if Kansas possessed any rights in the water before 1876 , they could not be afterwards diminished by the admission to the Union of another State.

When the case came on for final hearing in 1907 the United States claimed to intervene on the ground of a paramount interest in the controversy. It was argued that by virtue of superior sovereignty the Federal Government was entitled to deal with all flowing waters for the general benefit of the whole community, irrespective of the local and conflicting interests of particular States. Such wide powers found no place in the actual words of the Constitution, but counsel argued that they were to be

1 I hope this brief statement sufficiently summarises the essential facts. 347 witnesses were examined. and the evidence amounted to 8,559 typewritten pages, with 122 exhibits ( 206 U. S., I05-6). See also the conclusions of the Court, p. 36, post: 
implied from the power given to Congress to " regulate commerce." The Court, however, refused to hold that powers so extensive could be conferred by mere implication or to read into the Constitution a general authority to Congress to undertake the reclamation of arid lands. Congress could regulate navigable rivers, but the Arkansas was not navigable in either of the two States, and its navigability lower down was admittedly unaffected by the irrigation works in Colorado. The intervention of the United States was therefore dismissed without prejudice to any claim that might arise concerning the navigable portion of the river.

The adjustment of the conflicting rights of the two States was a more difficult matter. The first problem was to find a rule of law by which to decide the question. The law of Kansas was the English common law rule of the equal rights of riparian owners, with certain statutory modifications. Colorado, on the other hand, had declared in her Constitution that the ownership of all unappropriated waters within the State was vested in the public, which was expressly entitled to divert them for beneficial uses. Neither State could enforce its rule upon the other, and there was no Federal statute or other superior law governing both parties.

This difficulty, however, did not deter the Court. If no law existed, the Court was quite prepared to make one. The Constitution gave it jurisdiction in cases involving questions of "law or equity," and "law" in 1787 meant the English common law, at any rate in general outline. ${ }^{1}$ This the Court was prepared to supplement, if required, by the rules of international law, and cited a well-known dictum of its own delivered in one of the prize cases arising out of the Spanish War of I898: 
"International law is part of our law, and must be ascertained and administered by the courts of justice of appropriate jurisdiction, as often as questions of right depending on it are duly presented for their determination." 1

And Chief Justice Fuller had himself remarked in the first stage of the present case:

"Sitting, as it were, as an international, as well as a domestic tribunal, we apply Federal law, State law, and international law, as the exigencies of the particular case may demand." 2

And finally

"Through these successive disputes and decisions this Court is practically building up what may not improperly be called inter-State common law." 3

The cardinal rule governing every question was declared to be that of the equality of States.

"Each State stands on the same level with all the rest. It can impose its own legislation on no one of the others, and is bound to yield its own views to none. . . . Surely here is a dispute of a justiciable nature which must and ought to be tried and determined. If the two States were absolutely independent nations it would be settled by treaty or by force. Neither of these two ways being practicable it must be settled by decision of this Court." 4

Acting upon these main principles the Court went on to analyse the rights of the parties to the case. The claim of Kansas to treat the matter as one merely of ordinary riparian rights was rejected, as was the right

1 The Paquete Habana (1900); 172 U. S., 700.

2185 U. S., 146.

3206 U. S., 98.

4206 U. S., $97-8$. 
claimed for Colorado to deal as she pleased with the whole body of water. Nor was Colorado to be allowed to appropriate all the water and to recompense Kánsas by something else of equal value; for the Court to allow this would be for it to make a bargain between the parties. On the other hand, the Court would consider the general benefit to the land in both States.

"For instance, if there be many thousands of acres in Colorado destitute of vegetation, which by the taking of water from the Arkansas River and in no other way can be made valuable as arable lands producing an abundance of vegetable growth, and this transformation of desert land has the effect, through percolation of water in the soil, or in any other way, of giving to Kansas territory, although not in the Arkansas valley, a benefit from water as great as that which would inure by keeping the flow of the Arkansas in its channel undiminished, then we may rightfully regard the usefulness to Colorado as justifying its action, although the locality of the benefit which the flow of the Arkansas through Kansas [causes] has territorially changed. . . .

"Will not the productiveness of Kansas as a whole, its capacity to support an increasing population, be increased by the use of the water in Colorado for irrigation? May we not consider some appropriation by Colorado of the waters of the Arkansas to the irrigation and reclamation of its arid lands as a reasonable exercise of its sovereignty and as not unreasonably trespassing upon any rights of Kansas?" 1

Mr. Justice Brewer went on to point out that the Kansas law itself recognised the right of appropriating water for irrigation, subject to an equitable division among the riparian proprietors. He further observed that a strict application of the common law rule might result in Okla-

1206 U. S., 100-2. 
homa making the same claim against Kansas which Kansas was now making against Colorado, with the practical result that the river could not be used for irrigation purposes at all.

As the final decision in the case is somewhat complisated, it is best stated in the language of the Court:

"We are of the opinion that the contention of Colorado of two streams ${ }^{1}$ cannot be sustained; that the appropriation of the waters of the Arkansas by Colorado for the purpose of irrigation, has diminished the flow of water into the State of Kansas; that the result of that appropriation has been the reclamation of large areas in Colorado, transforming thousands of acres into fertile fields and rendering possible their occupation and cultivation when otherwise they would have continued barren and unoccupied; that while the influence of such diminution has been of perceptible injury to portions of the Arkansas valley in Kansas, particularly those portions closest to the Colorado line, yet to the great body of the valley it has worked little, if any, detriment, and regarding the interests of both States and the right of cach to receive benefit through the irrigation and in any other manner from the waters of this stream, we are not satisfied that Kansas has made out a case entitling it to a decree. At the same time it is obvious that if the depletion of the waters of the river by Colorado continues to increase, there will come a time when Kansas may justly say that there is no longer an equitable division of benefits and may rightly call for relief against the action of Colorado, its corporations and citizens, in appropriating the waters of the Arkansas for irrigation purposes.

"The decree which, therefore, will be entered will be one dismissing the petition of the intervenor, without prejudice to the rights of the United States

1 This refers to an argument put forward by Colorado based on certain technical scientific evidence. See 206 U. S., 52-4, II5. 
to take such action as it shall deem necessary to preserve or improve the navigability of the Arkansas River. The decree will also dismiss the bill of the State of Kansas as against all the defendants, without prejudice to the right of the plaintiff to institute new proceedings whenever it shall appear that through a material increase in the depletion of the waters of the Arkansas by Colorado, its corporations or citizens, the substantial interests of Kansas are being injured to the extent of destroying the equitable apportionment of benefits between the two States resulting from the flow of the river. Each party will pay its own costs." 1

A few remarks suggest themselves upon the five cases noted in this chapter. Two out of the five disputesCherokee Nation v. Georgia and Louisiana v. Texasarose from real political antagonism. In each of these two cases the defendant State was accused of deliberately viclating the plaintiff's rights with the object of causing a definite injury. The three remaining cases were all controversies arising from conflicting interests in the use of inter-State rivers. In these, although the States concerned did not agree as to their respective rights, there was no suggestion of political antagonism or of deliberately injurious conduct. The cases in which the Cherokees and Louisiana were the piaintiffs were of the kind which between independent nations might easily have led to war. The three river cases, on the other hand, all belonged to the class of dispute which nations habitually submit to arbitration. None of them could possibly have provoked an armed conflict unless the parties were intent on war for other reasons.

That being so, it is somewhat remarkable that in each of the two really serious cases a majority of the Court dismissed the bill on rather narrowly technical grounds,

1206 U. S., 117. 
and refused to investigate the merits of the plaintiff's complaint. There is of course no need to suggest that the judges deliberately shirked a delicate and disagreeable duty. But the Court has always been reluctant, even in the clearest cases, to pass the slightest word of censure upon the conduct of a State, and it is possible that this reluctance may have unconsciously biased the judges in favour of the technical arguments which enabled them to avoid pronouncing a judgment that would have involved the severest moral censure upon the delinquent.

The three river cases do not call for much comment. South Carolina v. Georgia was easily decided on the ground that the Constitution had vested in Congress sufficient authority to execute the improvements in question. Missouri v. Illinois was also a fairly simple case, since the evidence showed that no nuisance had in fact been caused by the acts complained of. Kansas v. Colorado is more interesting, because it illustrates the difficulty with which an international court must frequently be faced of having no accepted rule of law applicable to the particular dispute. The laws of the two States upon the subjectmatter of the controversy were in sharp conflict, and there was no rule of superior authority binding upon both parties. It is by no means satisfactory for litigants to have their dispute settled according to a rule manufactured by the Court to meet the particular emergency. The actual decision reached was in the nature of a compromise, as is often the case in international arbitrations. 


\section{CHAPTER VI}

\section{THE ENFORCEMENT OF JUDGMENTS}

"John Marshall has pronounced his judgment: let him enforce it if he can!" With this scornful challenge President Andrew Jackson emphasised the chief difficulty that must confront any court which issues commands to litigants more powerful than itself. The words were spoken in 1832 , and referred to one episode in the long but unsuccessful resistance of the Cherokee Indians to Georgian oppression. ${ }^{1}$ Marshall, a zealous Federalist, led the Supreme Court in its keen solicitude for the honour of the United States, which was deeply pledged by solemn treaties with the Indian tribes. Jackson, a rough soldier from the frontier of Tennessee, cared little for Indian rights and little for the judicial settlement of disputes. $^{2}$

For more than thirty years Marshall's powerful mind had guided the Supreme Court in a policy of emphasising and extending the powers of the Federal Government at the expense of the rights claimed for the separate States. At the time of the conflict with Georgia he was an old man, and he died in 1835 . The inauguration of President Jackson in 1829 had marked the end of the old Federalist party. Jackson was carried into office on the top of a great wave of popular feeling, which demanded a vigorous reassertion of State rights. The whole of the

1 Worcester v. Georgia, 6 Peters, 5I5.

2 When the Indians appealed to Jackson to enforce the treaties he replied "that the President of the United States has no power to protect them against the laws of Georgia" (5 Peters, 9). 
South and West, together with the great States of New York and Pennsylvania, were solidly behind him. His opponent, President Adams, carried only New England and the three smallest of the Middle States. The election was regarded as a great triumph for democracy, and among the defeated enemies of democracy popular feeling included Marshall and the Supreme Court. Georgia successfully maintained her resistance to its decrees. ${ }^{1}$ The Cherokees were ultimately driven beyond the Mississippi, and the result of the whole conflict was a victory for the principle of State sovereignty over the principle of the judicial settlement of inter-State disputes.

Under the patronage of Jackson and his successors the Supreme Court was gradually filled with judges who made no further attempt to extend the powers of the Federal Government at the expense of the States.

Another incident of Jackson's presidency should here be noticed, although it did not involve the question of actual resistance to the Court. The grant of a charter in $179 \mathrm{I}$ and again in 1816 to the Bank of the United States had aroused bitter popular hostility, and the legality of the action had been challenged in the Supreme Court, which in I8I9 had decided in favour of the Bank. ${ }^{2}$ The charter was due to expire in 1836. In 1832 Congress passed a bill for its renewal, which was vetoed by the President. In his message to Congress Jackson asserted his right and duty under the Constitution to exercise his own judgment on the question of the constitutionality of the Bank, irrespective of the judgment of the Supreme Court. In taking this action he was undoubtedly supported by the public opinion of the day, and his Attorney-General, Roger Taney, advised him that he

1 In one instance she actually executed a Cherokee in defiance of a writ of error addressed to the Georgian courts by the Supreme Court of the United States (5 Peters, I2).

${ }^{2}$ McCulloch v. Maryland, 4 Wheaton, 316. 
was right. Upon the death of Marshall in 1835 Taney was appointed Chief Justice of the Supreme Court. In that capacity in 1857 he delivered the decision of the majority in the Dred Scott case. ${ }^{1}$

The Dred Scott judgment, viewed in the light of history, so far from being a means of averting war, must be reckoned as one of the causes directly contributing to the outbreak of the Civil War. To understand its significance we must go back to 1820 and recall the "Missouri Compromise" of that year. That agreement had provided that Missouri should be admitted to the Union as a slave State, but that for the future there should be no more slavery west of the Mississippi north of the latitude of $36^{\circ} 30^{\prime}$. In the Dred Scott case it was decided that a slave taken by his master to a free Territory remained a slave and the property of his master. The Court further declared that the Missouri Compromise was invalid and that slavery in the Territories could not be abolished either by Congress or by the Territorial legislatures.

The decision once given could not be overruled except by constitutional amendment. Such an amendment would require the concurrence of three-fourths of the State legislatures, which was clearly impossible. On the $5^{\text {th }}$ December, I860, Lincoln was formally elected President of the United States. He had already committed himself to the doctrine that "this government cannot endure half slave and half free." His election notified the determination of the North and West that slavery should not be tolerated outside the existing Southern States, and the South also rightly interpreted it as meaning that for the future the government of the Republic had definitely passed into the hands of their opponents. The answer to the challenge was not slow in coming. On the 20 th December the Convention of South Carolina repudiated

1 Scott v. Sandford, ig Howard, 393. 
the Constitution of the United States and declared that South Carolina resumed her sovereign place among the nations. The remainder of the Cotton States soon ranged themselves by her side. On the I2th April, I86I, South Carolina fired upon the Stars and Stripes at Fort Sumter and the war began.

It is necessary to glance briefly at these political matters if we would appreciate correctly the relation of the Supreme Court to the gravest conflict in American history. The Dred Scott judgment was a decision in favour of the South. Of the nine judges then composing the Court the Chief Justice and four others were Democrats from the slave States. Of the four from the free States two were Democrats and two were Whigs. The strict legal requirements of the dispute called for nothing more than a ruling upon the personal status of Dred Scott, and Mr. Justice Nelson, a Democrat from New York, confined himself to this point. But the majority of the Court could not resist the temptation to pronounce an opinion upon the great constitutional question. Taney thought that the Court had now the chance of finally settling the slavery controversy as the South desired it to be settled, and some outside pressure was brought upon the five Southern judges to take this course. The Court unfortunately was divided along party lines, the two Whig judges dissenting from the opinion of the majority. ${ }^{1}$ The result of the judgment was the exact opposite of what Taney had expected and hoped. Instead of settling the question of slavery in the 'Territories once and for all it only served to pile fresh fuel upon the abolitionist agitation and to let loose a torrent of indignation upon the Court itself. Many violent and unjust things were said about the judges, who had undoubtedly de-

1 The luminous judgment of Mr. Justice Curtis became one of the chief political documents of the Republican patty. 
cided in accordance with their sincere convictions. It was generally believed among Republicans, and the charge was even countenanced by Lincoln, that the decision had been arranged between President Buchanan and the Chief Justice. The accusation was quite unjust to both men, but in the heated atmosphere of the time it was inevitable that it should be made and believed. The only conclusion which we can draw to-day from the whole episode is that in 1857 the slavery dispute had already reached a stage at which it could no longer be solved by an appeal to any court of law.

A discussion of the Dred Scott case may at first sight appear to have little bearing upon the subject of the present chapter, since the judgment was actually obeyed without further question by the parties concerned. The parties were two private individuals and the only question presented formally for determination was whether Scott could maintain an action for assault and battery against his master, Sandford. But the real importance of the judgment lay in the solemn decision of the judges that Congress had no power to exclude slavery from the Territories of the United States, and that the famous Missouri Compromise of 1820 , which purported to do so, was invalid. Upon this great issue the judgment of the Court was not accepted or obeyed, for it was overthrown by the victory of the North in the Civil War. After the war, while the South lay under the heel of the North, the judgment was legally got rid of by the Thirteenth and Fourteenth Amendments, which abolished slavery and made the negroes citizens of the United States.

At no time was the Supreme Court asked to decide upon the question whether a State could lawfully secede from the Union. It is obvious that any State which was prepared to secede must have assumed that its action was justifiable; and if so, the mere fact of secession would 
make it an independent State no longer subject to the jurisdiction of the Supreme Court.

Turning now to the other cases noted in previous chapters we shall find that the question of the enforcement of judgments is one that has been continually present to the minds of the judges. It was argued at some length in the case of Chisholm v. Georgia in $1793,{ }^{1}$ where counsel for the plaintiff, after tentatively suggesting that the decree might be enforced by the seizure of specific property, was driven at last to envelop the whole matter in a cloud of rhetoric.

"Still, we may be pressed with the final question: "What if the State is resolved to oppose the execution?' This would be an awful question indeed! He to whose lot it should fall to solve it would be impelled to invoke the god of wisdom to illuminate his decision. I will not believe that he would recall the tremendous examples of vengeance, which in past days have been inflicted by those who claim, against those who violate, authority. I will not believe that in the wide and gloomy theatre, over which his eye should roll, he might perchance catch a distant glimpse of the Federal arm uplifted. Scenes like this are too full of horror not to agitate, not to rack, the imagination. . . But that any State should refuse to conform to a solemn determination of the Supreme Court of the Union is impossible, unless she shall abandon her love of peace, fidelity to compact, and character."

The Court did not determine the question, Mr. Justice Blair expressing the hope that coercion would be unnecessary. What actually happened was that Georgia passionately refused to comply with the judgment, and was supported in her refusal by public opinion throughout the States. The particular controversy was settled by the

12 Dallas, 419.

22 Dallas, 427-8. 
Eleventh Amendment, ${ }^{1}$ but the fact remained that the first decree entered in the Supreme Court against a State of the Union had been contemptuously and successfully defied.

In the case of Rhode Island v. Massachusetts (1838) ${ }^{2}$ counsel for Massachusetts, arguing against the jurisdiction of the Court, laid stress upon the fact that no means existed for enforcing any judgment that might be delivered. To this counsel for Rhode Island replied:

"No process would necessarily follow a final decree in this cause. We ask no damages of Massachusetts; no delivery of possession; no process to compel her to do or to undo anything. All we ask is a decree, ascertaining and settling the boundary line between the two States." 3

The Court did not feel bound to decide the question, and as the judgment ultimately went in favour of the defendant State, which was in possession, no problem as to execution was presented.

The case of Kentucky v. Dennison, Governor of Ohio ( 1860$)^{4}$ was not in form a suit against a State, but the Court rightly took the view that the State of Ohio was the real defendant. Kentucky demanded that the Governor should be ordered to give up a fugitive from justice, a free negro who was accused of helping a slave to escape. The Constitution (Art. IV, Sec. 2) and a Federal statute of 1793 expressly direct the surrender by State officials of all fugitives from justice escaping from other States. The constitutional provision covers cases of "treason, felony, or other crime," and the Act of 1793 uses the same words. On the other hand, Ohio was a State where anti-slavery feeling was strong, and Denni-

1 See p. 9, ante.

212 Peters, 657.

3 I2 Peters, 705.

424 Howard, 66. 
son had just been elected as Governor by the Republican party after a sensational campaign. The whole atmosphere was charged with forebodings of war.

Chief Justice Taney, delivering the opinion of the Court, laid down in the first place that the Governor was obliged under the Constitution and statute to deliver up all fugitives from justice, even though the acts with which they were charged might not be offences according to the Ohio law. The Governor's duty, he said, was purely ministerial and did not permit him to form any opinion as to the merits of the particular case. The Union of the States was " a compact binding them to give aid and assistance to each other in executing their laws, and to support each other in preserving law and order within its confines, whenever such aid was needed and required." 1 Without such mutual support, said the Chief Justice, the Union must fail.

Having thus emphasized the Governor's duty under the Constitution, Taney concluded his judgment by observing that no means existed for compelling its enforcement.

"The act does not provide any means to compel the execution of this duty, nor inflict any punishment for neglect or refusal on the part of the Executive of the State; nor is there any clause or provision in the Constitution which arms the Government of the United States with this power. Indeed, such a power would place every State under the control and dominion of the General Government, even in the administration of its internal concerns and reserved rights.

"But if the Governor of Ohio refuses to discharge this duty, there is no power delegated to the General Government, either through the Judicial Department or any other department, to use coercive means to compel him. And upon this ground the motion for the mandamus must be overruled."

${ }_{24}+$ Howard, 100.

2.4 Howard, 107, 109-10. 
Taney was an earnest believer in slavery and at the same time an earnest believer in State rights, and he certainly deserves full credit for a judgment in which respect for these two principles was so ingeniously combined. It need hardly be added that the fugitive was not in fact surrendered.

To understand this controversy properly it should be remembered that in I850 Congress, then under Southern influence, had passed a stringent "Fugitive Slave Act," to be enforced in all States by Federal officials. The mere affidavit of the master was made conclusive evidence of the ownership of a slave. The result was that in the North fugitives were often rescued from Federal custody by mobs, with the open approbation of influential and respectable men. Furthermore the legislatures of the Northern States, including Ohio, passed acts the whole object of which was to make the enforcement of the Federal law as difficult as possible. ${ }^{1}$ In these circumstances it was not likely that, where anti-slavery feeling was aroused, the State authorities would be more likely to obey the judicial than the legislative organ of the Federal Government.

Many years passed before the question of enforcing a decree against a State was again argued in the Supreme Court. Most of the cases heard were boundary disputes which aroused no strong political feeling; in some instances the question was submitted to the Court by mutual consent, and in every case the line as defined by the Court was accepted by both States. There have been three cases, namely, Louisiana v. Texas, Missouri v. Illinois, and Kansas v. Colorado, ${ }^{2}$ in which the plaintiff

1 The Supreme Court of Wisconsin went so far as to release an offender by habeas corpus from the custody of the United States Marshal, and refused to comply with a writ of error directed to it from the Supreme Court of the United States. See Ableman v. Booth (r858), 2 I Howard, 506.

2 See Chapter V, antc.

P. 4345

G 
sought an injunction restraining the defendant State from committing the acts complained of, but since the decision of the Court in each case was in favour of the defendant, the question of enforcing an injunction did not arise. In United States v. Michigan $(1903)^{1}$ the parties came to an agreement after the main question had been decided in favour of the United States.

The case of South Dakota v. North Carolina in $1904^{2}$ revived the problem of enforcement but as a matter of form rather than of substance. The decision, as we have already seen, was to the effect that South Dakota was entitled to recover from North Carolina the sums due upon certain State bonds which had been assigned by private holders to the plaintiff State. The relief claimed by the bill followed the precedent of private suits, demanding the usual remedy by foreclosure and sale in default of payment. This remedy was possible in the particular case, since the bonds had been issued in order to effect a mortgage of certain railway stock held by the State and the stock was expressly declared to be collateral security for the bonds.

The Court in its judgment ranged at large over the question of execution, citing the dicta of various judges to the effect that it could neither order the property of a State to be seized nor a tax to be levied. But in this particular case, since the debt was secured by the mortgage of specific property, it was held that the ordinary remedy by foreclosure could be applied. A decree was accordingly entered directing that unless the sum due was paid by a certain date the marshal of the Court should sell the stock by public auction in Washington to satisfy the plaintiff's claim. ${ }^{3}$

1 See Chapter IV, ante.

${ }^{3}$ I92 U. S., 32I-2.

2 I92 U. S., 286. 
The decision of the Court was that of a bare majority, Mr. Justice White (now Chief Justice) observing on behalf of the minority:

"I take it to be the elementary rule of public law that, whilst the contracts of a sovereign may engender natural or moral obligations, and are in one sense property, they are yet obligations resting on the promise of the sovereign and possessing no other sanction than the good faith and honour of the sovereign itself." 1

The minority view is of more than merely academic interest, since the Supreme Court of the United States, unlike the British House of Lords, holds itself free at any time to reverse its own previous decisions. There is therefore always a possibility that the opinion of a minority may in the course of time become the basis for a judgment of the Court.

It is in our own day that the question of enforcement has taken its most serious form. The successful resistance of Georgia to the Court in early days occurred only in cases where private individuals were the plaintiffs. The seriousness of the situation recently created by the case of Virginia v. West Virginia lies in the fact that it was in effect the repudiation by a State of its obligation under the Constitution to accept the Supreme Court as the final arbiter in inter-State disputes.

We have already seen ${ }^{2}$ that on the I4th June, I9I5, after prolonged litigation, in which every possible consideration was shown by the Court to the defendant State. Virginia obtained a decree for the payment of the sum of over twelve million dollars, with interest at five per cent. to run until payment. The case had been exhaustively considered by the Court, and every possible defence to

1 I92 U. S., 341-2.

${ }^{2}$ Ante, p. 7I. 
the claim had been carefully examined with a full sense of what was due to the dignity of the parties and the importance of the controversy. Upon the merits of the case nothing further remained to be said, and the decision was rendered by an unanimous Court.

Virginia then waited for a year, but nothing happened. Then she noved in the Supreme Court ${ }^{1}$ for a writ of execution. In reply to this motion West Virginia pleaded that she could not obey the judgment except through the action of her legislature, which would not meet until January, I9I7. She alleged further that she had no property subject to execution, and concluded by denying that the Supreme Court had any authority whatever to enforce a money judgment. Upon these two last points the Court found it unnecessary to express an opinion at the time, but they accepted the view that West Virginia should not be forced to act until her legislature had met. The motion for a writ of execution was therefore refused "without prejudice to the renewal of the same after the next session of the legislature of the State of West Virginia has met and had a reasonable opportunity to provide for the payment of the judgment." 2

The legislature of West Virginia accordingly met, held its ordinary session, and adjourned without making any attempt to satisfy the judgment. In I9I 8 the question of execution therefore came before the Supreme Court again, ${ }^{3}$ and gave Chief Justice White the opportunity for a long and learned survey of the whole problem, in which he examined the history of the colonial jurisdiction of the British Privy Council and also the voluminous records of the discussions preceding the adoption of the Federal Constitution. In those debates, as was natural, divergent views had found expression, and the Chief Justice cited several opinions which strongly favoured the grant of

1241 U. S., 531.

$224 \mathrm{I}$ U. S., 532.

${ }^{3} 246$ U. S., 565 . 
coercive powers to the Federal Government. As a matter of history it is, however, quite clear that most of the States would never have entered the Union if they had imagined that thereby they were submitting themselves to the possibility of Federal coercion. Of the contemporary papers by far the most important is The Federalist, the series of collected essays in which Alexander Hamilton, the leader of the Federalist party, together with Madison and Jay, urged the people of New York State to give their adherence to the Constitution. In No. 8I of this work Hamilton alludes to the alarm caused by the suggestion that the establishment of Federal Courts might render States liable to be sued for their debts. Upon this he remarks:

"It is inherent in the nature of sovereignty not to be amenable to the suit of an individual withou: its consent. . . Unless therefore there is a surrender of this immunity in the plan of the convention, it will remain with the States, and the danger intimated must be merely ideal. . . . There is no colour to pretend that the State governments would, by the adoption of that plan, be divested of the privilege of paying their own debts in their own way, free from every constraint but that which flows from the obligations of good faith. The contracts between a nation and individuals are only binding on the conscience of the sovereign and have no pretensions to a compulsive force. They confer no right of action independent of the sovereign will. To what purpose would it be to authorise suits against States for the debts they owe? How could recoveries be enforced? It is evident it could not be done without waging war against the contracting State; and to ascribe to the Federal courts by mere implication, and in destruction of a pre-existing right of the State governments, a power which would involve such a consequence, would be altogether forced and unwarrantable." 
Hamilton is speaking only of suits by individuals, but it is clear from the last words of the passage quoted that he did not believe in the possibility of any power of enforcing the judgments of the Supreme Court against a recalcitrant State. When we remember that Hamilton was the chief representative of the extreme Federalist view it is obvious that the general opinion of his day would never have tolerated the notion of the forcible execution of the Supreme Court's decrees against a State. Especially is it certain that the people would never have agreed to the use of force for the collection of debts due from one State to another.

The ideas of I 788 need not be accepted in 19I8, unless they have been embodied in a document of binding force, and upon this great question of enforcing judgments the Constitution was discreetly silent. The Chief Justice accordingly proceeded to examine the claims of the parties before the Court. Virginia contended that the judgment of the Supeme Court bound the defendant State "in a governmental capacity," and rendered State property liable to execution. She claimed further that the Court could order the West Virginia legislature by mandamus to levy a tax to pay the debt, a practice frequently adopted when the defendant was a city corporation or other municipal authority.

All these contentions were expressly denied by West Virginia, which claimed in general terms " that the defendant as a State may not, as to its powers of government reserved to it by the Constitution, be controlled or limited by process for the purpose of enforcing the payment of the judgment." 1

The judges, overruling the argument of West Virginia on the general question, held that the Court had authority over the State government, and that the right to pro-

1246 U. S., 594-5. 
nounce a judgment implied the right to use the appropriate means for its enforcement. Numerous decisions given in private suits were cited to lend authority to this somewhat obvious proposition. There is no difficulty in stating as an abstract and general principle that the judgments ought to be enforced. The real problem is to decide upon the ways and means, or, as the Court said, "What are the appropriate remedies for such enforcement?" 1

Here the Chief Justice was on more difficult ground. He began by saying that it was within the power of Congress to enforce the judgment by special legislation, and that this power was derived from the necessity of procuring the assent of Congress to the contract of I86I creating the debt. ${ }^{2}$ This, we may remark, would be in effect shifting the responsibility on to other shoulders. The Court could not issue orders to Congress, nor was Congress under any legal obligation to help the Court out of its difficulties. All that the Chief Justice could mean was that, if Congress chose to pass a law for the coercion of West Virginia, the Supreme Court would be prepared to hold it valid. On general principles it would seem undesirable that such an opinion should be formally published before any statute had been actually passed.

In the second place the Chief Justice went on to consider "the appropriate remedies under existing legislation." Virginia was asking for a mandamus directly ordering the West Virginian legislature to levy a tax to meet the judgment. This of course was the crux of the whole matter and the Court decided to postpone its solution of the difficulty. The Chief Justice treated the question as being "whether there is power to direct the levy of a tax adequate to pay the judgment and provide for its enforcement irrespective of State agencies." 3 The Court
1246 U. S., 600.
2246 U. S., 60I-3.
3246 U. S., 604. 
directed the case to be adjourned for further argument upon this point, together with the question of the possibility of execution upon State property. In deciding upon this further postponement the Court expressed a wish to give West Virginia another opportunity of complying with the judgment and at the same time to give Congress an opportunity of taking such action as it might think fit.

Since the rendering of the judgment wiser counsels have prevailed with the West Virginian authorities, and an act has now been passed levying a tax for the gradual extinction of the debt, nearly four years after the pronouncement of the decree and fifty-six years after the debt was contracted. Had it been decided to prolong the resistance, it is not easy to see what the next step would have been. Even if the Court in such a case should decide to order the levy of a tax or the sequestration of certain property there is no security that the controversy would be thereby ended. The defendant State might be no more willing to comply with such orders than with the original decree. Or again if Congress should consent to pass coercive legislation we cannot be sure that it would be obeyed. Federal legislation has before now been successfully resisted by recalcitrant States, and what has happened before may happen again. Should the worst come to the worst, no means of enforcing such a decree will remain save the employment of Federal troops. Fortunately for the peace and fraternity of the Union, West Virginia has decided not to force the matter to such a grave crisis. Even an outsider may be permitted to observe that the repudiation of a debt solemnly contracted is not the best ground upon which to fight for an assertion of "sovereign" rights, and if this grave issue must one day be decided, it is better that the resisting State should be able to found her claim upon some higher ground of 
THE ENFORCEMENT OF JUDGMENTS I05 justice and policy. But the "more perfect Union" grows stronger as the years go on, and as the echoes of old controversies die away we may hope that no State will seek to reawaken them by a fresh challenge to the authority of an united nation. 


\section{CHAPTER VII}

\section{GENERAL CONCLUSIONS}

IT remains to ask whether we can draw from these cases any practical lessons for our own day. When we are seeking to set up a Court of the Nations as a means of avoiding war, what can we learn from the history of the Supreme Court of the United States?

It is possible to err in two ways. Both the extreme partisans and the extreme opponents of a League of Nations may by selecting their evidence find much to support their particular points of view. The advocates of the one side can rightly say that in the great majority of cases the decrees of the Court have been loyally obeyed and have given satisfaction to both parties. On the other hand it may be urged that in cases where strong passions have been aroused the decrees have been successfully resisted, and that even in our own day the Court has been for a time faced with the grave problem of how to enforce its decision upon a recalcitrant State.

To form a right judgment we must view the matter in the light of history. When the scheme of a Federal Supreme Court was propounded for the consideration of the States in $I 787$ it was received in many quarters with the fiercest opposition. At the present day it may be fairly said that the gloomy prophecies indulged in by its opponents have been entirely falsified. Although its early decisions leaned strongly towards Federalism, the Court has not lowered the dignity of States nor encroached upon the rights reserved to them under the Constitution. 
It has never attempted to reduce them to the position of mere provinces subordinate in all things to the will of the central government. The balance has been on the whole evenly held between the Federal Government and the individual States, as well as between the several States in their relation to one another. In cases not depending upon the interpretation of particular documents the Court has based its decisions upon the broad principles of international law. The doctrine of the absolute equality of all States has been faithfully observed, and no suggestion has ever been made that the judges have been actuated by any desire to propitiate the stronger at the expense of the weaker States.

The limited scope of this essay has not permitted us to examine in detail the procedure followed in inter-State cases. But the lawyer who cares to study the procedure in the original reports will be impressed with the careful concern which the Court has always shown for the dignity and convenience of the litigating States. Rules which are strictly applied to ensure the proper conduct of ordinary litigation are relaxed when the parties are States of the Union. Often the Court appears rather to advise than to command. Technicalities are disregarded so far as possible. As Mr. Justice Holmes remarked at one stage of the case of Virginia v. West Virginia (I9I I):

"The case is to be considered in the untechnical spirit proper for dealing with a quasi-international controversy, remembering that there is no municipal code governing the matter, and that this Court may be called on to adjust differences that cannot be dealt with by Congress or disposed of by the legislature of either State alone. . . . Therefore we shall spend no time on objections as to multifariousness, laches, and the like, except so far as they affect the merits, with which we proceed to deal." 1

1220 U. S., 27. 
Indeed there is no case which better illustrates the lengths to which the Court will go in its desire to respect the amour propre of a State, even where the conduct of the State does not call for sympathetic treatment. In I9I4 Chief Justice White said, in granting one of the numerous requests of the defendant State for further delay:

"We think it must be conceded that in a case between ordinary litigants the application of the ordinary rules of legal procedure would render it impossible under the circumstances we have stated to grant the request. We are of opinion, however, that such concession. should not be here controlling. As we have pointed out, in acting in this case from the first to last the fact that the suit was not an ordinary one between individuals, but was a controversy between States involving grave questions of public law determinable by this Court under the exceptional grant of power conferred upon it by the Constitution, has been a guide by which every step and conclusion hitherto expressed has been controlled. And we are of the opinion that this guiding principle should not now be lost sight of, to the end that when the case comes ultimately to be finally and irrevocably disposed of, as come ultimately it must in the absence of agreement between the parties, there may be no room for the slightest inference that the more restricted rules applicable to individuals have been applied to a great public controversy, or that anything but the largest justice after the amplest opportunity to be heard has in any degree entered into the disposition of the case. This conclusion, which we think is required by the duty owed to the moving State, also in our opinion operates no injustice to the opposing State, since it but affords an additional opportunity to guard against the possibility of error, and thus reach the result most consonant with the honor and dignity of both parties to the controversy." 1

1234 U. S., I2I. 
The reader will note the gradual growth of confidence in the Supreme Court as evidenced by the dates of the decisions. Jurisdiction having been denied in the Cherokee case in $183 \mathrm{I}$, no final judgment on the merits in any inter-State case was reached until the bill of Rhode Island against Massachusetts was dismissed in 1846. Altogether only three boundary disputes were decided before the Civil War. Fourteen boundaries have been definitely fixed by the Court in the period from I870 to our own day, and all the other cases that we have examined, with the exception of the unsuccessful suit against Governor Dennison of Ohio, fall within the same period.

The reason for this is to be found in the fact that until after the Civil War the Supreme Court had not really made its position secure. Until the Southern claims had been finally overthrown in battle American public opinion was largely dominated by the doctrine of "State Rights." Down to the time of Marshall's death in I835 the Supreme Court had always leaned to a "Federalist" interpretation of the Constitution, and this undoubtedly brought it into conflict with the general trend of American sentiment. President Van Buren ( $1837-184 \mathrm{I}$ ) once remarked that the Court would never have been created if the people could have foreseen what it would do. Historically there is little doubt that he was perfectly right. It was only with the greatest difficulty that some of the States were induced to accept the Constitution at all. Could they have foreseen the interpretations which Marshall was soon going to place upon its somewhat vague language it is perfectly certain that nothing would have induced them to agree to entrust the Federal Government with such wide powers. At the present day, taught by the wisdom of experience, we are able to see that Marshall's interpretation of the Constitution was the only one which could preserve it for future 
ages. Had the narrower doctrine of State Rights prevailed the Union would either have gone to pieces or have been forced to recast its Constitution. But we cannot altogether blame the men of an earlier day for not being prophets.

In the Civil War it was decided by the sword that the separate States had no right to withdraw from the Union. In other words they did not possess the most elementary attribute of sovereign communities, the right of deciding their own political destiny. Henceforth the "sovereignty" of the States became a legal fiction, and ceased to be any longer a historical or political fact. The word survives in the technical language of the law reports, but disappears from the speech of everyday life. In the Supreme Court we find Colorado claiming her "sovereign " right to deprive Kansas of water and other States demanding the "sovereign" privilege of repudiating their debts. But the decisions of the Court against these extreme claims are certainly supported by the common sense of the average American citizen.

The true inference to be drawn from history would seem to be that so long as the sense of State sovereignty was strong the Supreme Court was comparatively weak, and did not always command the confidence of the States. Since the theory of State sovereignty was overthrown by force of arms the Supreme Court has grown steadily in strength. Now that West Virginia has at last decided to comply with the judgment given against her in I9I5and American public opinion would probably have rendered a prolonged resistance ultimately impossible-we can say that there has been no case of State resistance to a decree of the Court since the Civil War. Opposition to the Court appears from time to time in American politics, but such opposition no longer follows State lines, and is not based upon any theory of State rights. 
The lesson of this for our own day would appear to be that the strength of any international Court will be in inverse proportion to the strength of national feeling in the States composing the league. No statesman of any country would suggest to-day that the nations of the world should surrender to any league powers anything like so great as those committed to the Federal Government by the Constitution of the United States. As Mr. Justice Brewer once said in the Supreme Court:

"It is no longer open to question that by the Constitution a nation was brought into being, and that that instrument was not merely operative to establish a closer union or league of States. Whatever powers of government were granted to the nation or reserved to the States (and for the description and limitation of those powers we must always accept the Constitution as alone and absolutely controlling), there was created a nation to be known as the United States of America, and as such then assumed its place among the nations of the world." 1

This essential fact of American history must always be borne in mind when we seek to institute comparisons between the Supreme Court and any possible tribunal of the League of Nations. It is neither possible nor desirable to fuse the existing civilised States of the world into a single nation and the tribunal will have to deal with States in which sovereignty is not merely a legal formula, but a political fact.

It must also be remembered that even the close ties which have united the American States into a single nation have not in all cases been strong enough to ensure compliance with the decrees of the Supreme Court. Georgia successfully defied the Court in the Chisholm and

1 Kansas v. Colorado (1907), 206 U. S., 80. 
Worcester cases, and her defiance was approved by the political opinion of the day. If the Court had ventured to assume jurisdiction of the Cherokee case there is no doubt that its decision would have been defied again. Georgia's action was deliberately taken in disregard of solemn treaties binding the United States, which under the Constitution (Art. VI) are declared to be the supreme law of the land. It is hardly likely that she would have shown any more respect for the judgment of a highly unpopular tribunal. As for the Dred Scott case, it aroused no direct resistance, because in form it was only a dispute between a negro and his master. But in substance it was a judicial decision that the South was right and the North was wrong, and there is no doubt that Lord Bryce correctly estimates its significance when he says:

"This judgment, since the language used in it seemed to cut off the hope of a settlement by the authority of Congress of the then ( 1857 ) pending disputes over slavery and its extension, did much to precipitate the Civil War." 1

Of the more recent cases the two which have caused the strongest political feeling have been Louisiana v. Texas and Virginia v. West Virginia. In the former case the Court declined to pass judgment upon the merits of the controversy; but it is by no means certain that Texas would have obeyed an adverse decision. West Virginia, after prolonging her resistance to the point of danger, has lately decided to obey the Constitution and the Court, but she has certainly shown no eagerness to comply with the decree pronounced in I9I 5 .

The present-day moral to be drawn from these cases is that we cannot afford to rely solely upon judicial means

1 The American Commonwealth (ed. 1911), vol. i, p. 264 . 
of settlement in cases which arouse strong national feeling and spring from a conflict of principles that cannot be resolved entirely by legal rules. These cases may be imagined in some such form as this:

A dispute arises between Utopia and Arcadia which inflames the national feeling of both countries and excites the keenest interest throughout the civilised world. It is referred to an international Court of five judges. Two of these come from States where popular sympathy is with Utopia, and two from countries where feeling runs high in favour of Arcadia. The fifth belongs to a country where feeling is sharply divided, as it has been in certain neutral States during the late war. Even the best and most upright of judges are but men, and their minds are moulded by the same influences as those of other men. It is almost certain that in such a case the decision of the Court will be rendered by a majority of three to two, and the actual result will depend upon the party in his own State to which the fifth judge happens to belong.

Mutatis mutandis, that is what happened in the Dred Scott case. It is also what happened in the Legal Tender Cases of 1870 and $187 \mathrm{I}$, where the Court in the later case reversed its own decision in the earlier case, the judges being divided exactly along party lines. In spite of the bitter things said about the judges at the time there is no doubt that they decided quite honestly according to their lights. But it is obvious that independent nations will never consider themselves to be bound by such a decision in cases where their honour or vital interests are at stake.

We are therefore driven to conclude that no possible Court of the Nations can provide us with an absolute security against war. This statement applies not only to cases of deliberate outrage. such as the Prussian raid upon the civilisation of Europe in I9I4, but to cases ․ P. 4345 
where there is an honest conflict of interests or ideals and good arguments can be urged on both sides. We are not, however, driven by such a conclusion to infer that a permanent international tribunal is an impracticable dream or that it involves an intolerable surrender of national rights. The history of the American Supreme Court and the history of international arbitration combine to negative any such merely cynical conclusion.

There are three possible methods of settling any dispute-agreement, litigation, and fighting. ${ }^{1}$ This is equally true of nations and of individuals. The practice of deciding individual quarrcls by fighting prevails to a greater or less extent, whatever the law may be, in all countries, and in no civilised community is it commoner than it is in some of the American States. ${ }^{2}$ Any European visitor who has the opportunity of travelling in the more out of the way parts of the Southern and Western States is apt to be surprised when he finds how widely recognised by public opinion is the right of private killing. For example, in some States it is practically impossible to procure a conviction for murder or even man-

${ }^{1}$ A stricter analysis might even reduce the alternatives to two by excluding litigation. If a legal decision is peaceably obeyed by both parties, the dispute has really been settled by agreement, that is to say, agreement to accept the judgment of the Court. If, on the other hand, one party refuses to comply, the decree can only be carried out, if at all, by invoking the aid of policemen, bailiffs, or other persons accustomed to use violence. In such a case the State really places a part of its fighting forces at the disposal of the successful litigant.

2 Professor J. C. Gray of Harvard throws an interesting sidelight upon this question (Nature and Sources of the Law, p. II): "In some of the United States,-as, for example, Texas,-statutes exempt property of debtors to a very large amount from being taken for their debts, and these statutes, judging from the language of the Courts, meet with the hearty approval of the public opinion of the neighborhood, as designed, they say, 'to cherish and support in the bosom of individuals, those feelings of sublime independence which are so essential to the maintenance of free institutions, (Franklin v. Coffice, is Tex., 416)."

When a man finds that the Courts will not effectively help him to collect his debts, it is possible that his "feelings of sublime independence" nay encourage him to rely upon his own resources. 
slaughter if the slayer is actuated by any reasonable degree of jez'susy. In other words, public opinion in such communities acts upon precisely the same principle which leads nations into war, that in certain cases which arouse strong passions men cannot be expected to allow lawyers to decide their quarrels for them. Yet even in the wildest and remotest of these communities no one would suggest that the existence of blood feuds is a good reason for abolishing all courts.

Boni judicis cst ampliare jurisdictionem; a good judge ought to aim at extending his jurisdiction. The real value of good courts is that they develop the habit of peaceful settlement at the expense of the habit of fighting. Even in the most violent communities tribunals that command the public respect will gradually draw to themselves an increasing number of disputes which would otherwise be settled by the use of firearms. All men are largely creatures of habit, and if the method of judicial settlement once comes to be regarded as normal it will gradually supersede, even though it may never entirely eradicate, the settlement of disputes by violent means. As Maine has pointed out, this is exactly what has happened in British India. The establishment of a system of honest and efficient tribunals has drawn to the bar a vast number of disputes which would otherwise have been settled by private vengeance.

It is precisely the same with nations. States are communities of men with the characteristics of men, and statesmen develop habits of government. In technical language, they follow precedents. If any international court which may be established is such as to command the confidence of the nations concerned it will, as time goes on, be entrusted more and more frequently with the solution of international controversies. As the American Supreme Court has more than once expressed it, the 
tribunal will succeed in making questions justiciable which were not regarded as justiciable before. It is not, humanly speaking, probable that all possible causes of international controversy will be brought within the range of judicial settlement. But if the Court by its actual practice justifies itself before the common judgment of civilised mankind, it is certain that the cases submitted to its decision will gradually increase in number and variety. Too much must not be expected at the start. More than half a century elapsed before the American Supreme Court rendered its first final decree in a suit between two States, and the problems which it has had to solve are simple compared with those which are likely to confront a tribunal holding jurisdiction over really independent nations. It can hardly be hoped that the Court will render perfect decisions in all cases, or that every decree will meet with a ready acceptance by the unsuccessful party. But every decision that is acknowledged to be just and every instance of ready compliance will help to make smooth the way toward the establishment of the ideal, which is nothing less than the rule of justice in international affairs. The immediate problem for the present day is to make a start in the right direction.

Another lesson which American history teaches us is this. Any problems which are certain to arise must be fully considered in advance, and rules for their solution must be set down in black and white. For the sake of immediate agreement the framers of the American Constitution deliberately avoided some awkward questions. They did not say whether Congress could regulate slavery; in fact the very words "slavery" and "slave" are absent from the document. Again they were silent upon the vital question whether a State could or could not withdraw from the Union. To leave those questions 
unsettled may have served their immediate purpose, but it was inviting war in the future. The great question of how to enforce the will of the whole upon the States is not dealt with explicitly, though much may be inferred. Nothing is said about the mode of enforcing compliance with judicial decisions, unless we can find it in the words whereby the President is made commander-in-chief of the Federal armed forces, and is charged (Art. II, Sec. 3) to " take care that the laws be faithfully executed." It was under the authority of these words that Lincoln took his measures against the Southern States in I86I.

The difficulty of providing in advance a permanent solution of all such questions is indeed great. But greater is the danger which lies in the policy of leaving them undetermined in the vague hope that a solution may after all never be required. Nations may fairly be expected to abide by obligations which they have undertaken with their eyes open, but they cannot be expected to acquiesce in decisions which, in the absence of specific rules, must depend on the personal opinions of a small body of judges. The decision in the Dred Scott case was of this character. The Constitution said nothing about the authority of Congress to deal with slavery, and the judges were therefore forced to decide according to their own private ideas of right and wrong. A legal judgment upon a great political issue delivered in such circumstances naturally carried no moral weight with those who did not already accept the view taken by the majority of the Court.

The greatest of all difficulties is of course the problem of enforcing upon the members of the League the common will, if there is one, of the whole body, whether that will be expressed through the judicial or through other organs. It must be admitted at the outset that in certain vital matters no State will consent in the last resort to 
accept any other will than its own. But even in the lesser matters which are entrusted to the judgment of the League it will be necessary to make express provision for the securing of obedience to the common will. If there is no explicit rule each State will be lawfully and honourably entitled, whenever the question arises, to act upon the interpretation that best suits its own interests. Unless the constitution of the League deals adequately with this essential matter the cause of judicial settlement will not in practice be advanced much further than it has already been carried by the existing system of arbitration treaties. ${ }^{1}$

Furthermore no Court of the Nations can possibly satisfy the world unless it administers a known and written code of international law. On many important questions of international law there is no general agreement and the actual practice of nations has in fact differed widely. The American Supreme Court could never have held the Union together without the express provisions of the written Constitution. The States could never have been induced to accept decisions fixing their relations to the United States or to each other if those decisions had rested on nothing better than the personal opinions of the judges. Hostility to the Court has been caused chiefly by its decisions upon the vaguer clauses of the Constitution. Its interpretation of a few ambiguous phrases has thrown open to Congress a vast field of activity which the public opinion of 1787 would almost certainly have reserved to the States. It cannot be expected that the nations of the modern world will be willing to leave important rights at the mercy of judges who are fettered by nothing stricter than their own predilections. Those

${ }^{1}$ This chapter was written before the publication of the League of Nations Covenant in the peace treaty with Germany. I have thought it best to leave the text as it was written without attempting to inquire how far the Covenant conforms to the principles which I believe to be sound. 
of us who have always lived in the atmosphere of the Anglo-American common law must also remember that in other jurisdictions the decisions of tribunals are not regarded as being in themselves decisive of the law. Continental lawyers do not consider that a disputed question is necessarily closed by a single decision of a superior Court. They are accustomed to clearly codified systems of law, and must not be expected to accept the English view that a court can be safely left to build up a system of law by its own decisions in particular cases.

If then we have correctly estimated the work of the Supreme Court of the United States, the practical lessons for our own time to be drawn from its history may be summarised as follows.

In the first place it is hopeless to expect that every possible cause of controversy between independent States admits of final settlement by judicial decision. Certain cases in which the existence, the honour, or the most vital interests of the nations are involved can only be settled by agreement or, in the last resort, by war.

Secondly, it is reasonable to hope that the establishment of a permanent tribunal constructed on sound principles will lead in the course of time to the growth of an international practice of submitting controversies to judicial decision; and if the conduct of the Court is such as to justify the expectations of its founders we may anticipate that the cases brought before its bar will gradually increase in number and variety.

Thirdly, it is essential that certain vital questions which must inevitably arise, such as the problem of ensuring compliance with decrees, must be clearly and unambiguously provided for in advance.

Fourthly, the judgments of the court will not command general assent unless it administers a definite and written system of international law drawn up by the 
agreement of all the States which become members of the League.

If the Court is established and developed upon sound principles, there is almost no limit to the services which it may ultimately render to the cause of international justice and peace. But if the desire to obtain a speedy agreement or the reluctance to tackle difficult problems tempts statesmen to lay the foundations badly, the experiment is bound to end in failure. The worst peril of failure is that it may lead men to the despairing conclusion that the peaceful and righteous settlement of international disputes is nothing better than an idle dream. 


\section{INDEX}

Account

Decreed between States, 68

Items of, considered by the Court, 70-I

ACCRETION

Defined, 4 I

Instances of, 42,53

Acquiescence (See Possession)

Agreements Between States

Effect of, considered, 36, 38-9, 43, 55, 67-8, 75-6

Suggested by the Court, 53, 68

Articles of Confederation, I, 3-5

Judicial provisions of, 4-5

Avulsion

Defined, 42

Instances of, 42, 47, 55-6

Bank of THE UNited States

Controversy concerning the charter of, 90

BoUNDARIES

Nature of, in America and in Europe, 34-5

Principles of decision applicable to, 56-9

Procedure in determining, 37

Doctrine of long possession applied to, 35, 36, 4I, 43, 50, 54,55

Doctrine of self-determination not applied to, 35, 39

In navigable channels, 42-3, 51, 76-7

Mathematical, 34, 36-7, 43, 44, 54

(See also Accretion, Avulsion, Rivers, and Thalweg)

Civil WaR, I86I-5

Relation of the Supreme Court to, 12, 9I-3

Claim by New York for money spent in, 65

Claims, Court of

Establishment of, $31-2,63$

Suits by States in, 32, 64-7

CODE

Necessity of, for an international tribunal, 88, I18-20

Constitution of the United States, Ch. I

Judicial provisions of, 7-9

Tenth Amendment to, I

Eleventh Amendment to, 9, 21, 95

Other Amendments to, I3, 93

Costs

Practice of the Supreme Court regarding, 37, 52, 81

Debts of the States, Ch. IV

Suits by individuals to recover, 9,60

Question of interest upon, 6I-2, 65, 70-1 
Embargo Upon Trade

Legality of, considered, 22-4, 77-9

ENGLish LaW

Position of, in American jurisprudence, 15, 57-8, 83

Execution, Ch. VI

Importance of the problem of, 117-18

FISHERY

Rights of, in territorial waters, 47-52

Foreclosure

Decreed against a State, 22, 98-9

Foreign States

Indian tribes not included among, 15. 73

Suit by Cuba against South Carolina not prosecuted, 75

Fugitives

Obligation of a State to surrender, 18, 95-7

GIFTS

Validity of, unaffected by motives and status of donor, 22 Hamilton, Alexander

Views of, upon the enforcement of decrees against States, IOI-2

INDIAN TRIBES

Legal position of, I5, 73-5, 89

INTERNATIONAL LAW

Applied by the Supreme Court, 3, 4I-3, 5 I, 53, 83-4

IRRIGATION

Injury by, $24-5,81-7$

IsLANDS

Disputes as to ownership of, 39-42, 47-52, 53

Jackson, President Andrew

Attitude of, towards the Supreme Court, 89-91

Jurisdiction of tine Supreme Court, Ch. II

Defined by the Constitution and Judiciary Act of 1789, 6-9

Curtailed by the Eleventh Amendment, 9, 2I, 95

MAPS

Effect of errors in, considered, 45-7

Marshall, Chief Justice

Influence of, upon the Constitution, Io, $89-90$

Missouri Compromise, i 820,91

Nuisance

Action for, against a State, 25-6, 79-8I

Political Questions

May become judicial, 17

Possession (See Boundaries)

Procedure, Rules of

Application of, where States are parties, 3, 36-7, 69, 107-8

Resistance

Instances of, to decrees of the Supreme Court. Ch. VI

Quarantine Laws

Action against a State based upon unfair administration of, $22-4,77 \cdot 9$ 
Riparian States

RIVERS

Rights of, in common stream, 24-6, 75-7, 79-8;

(See also Boundaries)

Banks of, as boundaries, $37-8,54-5$

Effect of changes in, upon boundaries, $39-42$

Jurisdiction of Congress over navigable, 75-7, 82-3

(See also Accretion, Avulsion, Boundaries, Nuisance, Riparian States, and Thaliveg)

SEA, ARMS OF THE

Question of boundaries in, 47-52, 52-3

SET-OFF

Question of, in actions upon State debts, 64

Sewage (See Nuisance)

Slavery

Controversy concerning, 91-3

SoverEIGNTY

Theory of, in the American Constitution, I-3, IIO

STATES

Equality of, 84

Duties of the governors of, 96-7

Supreme Court

Origin and functions of, Ch. I

Attitude of public opinion towards, 89-90, I09

Position of, in political controversies, 92-3

Influence of, considered, 1I-13, Ch. VII

Taney, Chief Justice

Opinion of, in Dred Scott case, 91-3

TAX

Question of mandamus to a State to levy, 102-4

Limits of State exemption from Federal, 65-7

TEXAS

Admission of, to the Union, 2, $+4-5$

THALWEG

TRADE

Rule of, explained and applied, 5 , 52-3

Liabilities of States engaging in, 65-7

Treaties

Boundaries depending upon, 39, 42-3, 44-5, 48

Violation of, by States, 73-5, 89

UNited States

Suits by, 29-30, 44-7, 6I-3

Suits against, $30-3,63-7$

Intervention of, in inter-State suits, 18, 82-3

Relation of, to the States, 1, 18, 66, 111

WAR

Power of tribunals to avert, discussed, Ch. VII

West VIRGINIA

Formation of, 19-21, 27, 38-9, 67-8

Reluctance of, to comply with decree of the Supreme Court, 28, 99-I05 




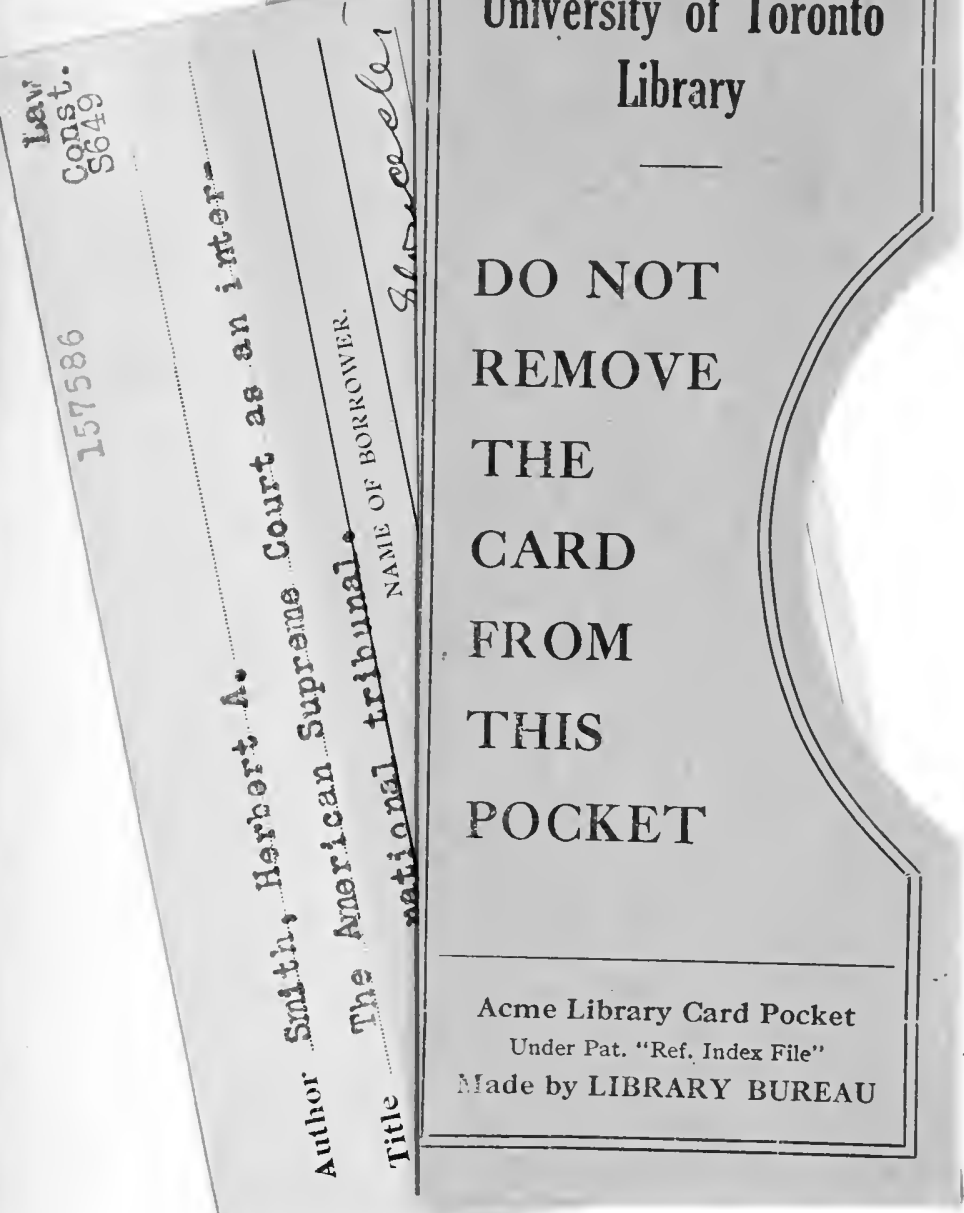


Mati

5.

(I)

1 (I)

1.

H.

H.

(1)

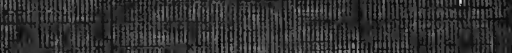

(1)

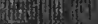

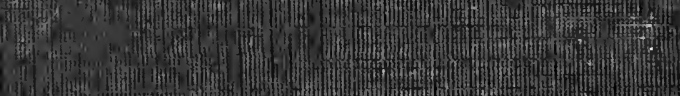

40 (1)

(1)

(15)

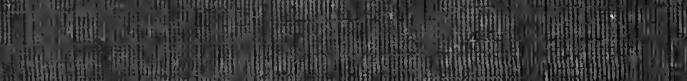

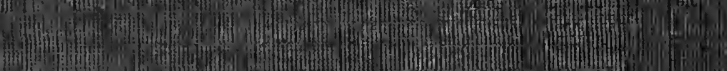

1

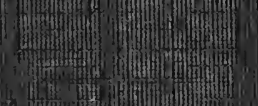

(1)

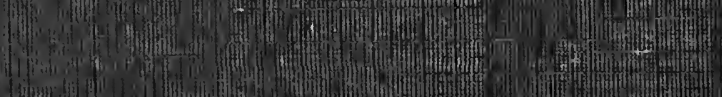

Hum (1) (1)

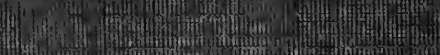

-

(2) (1)

(1)

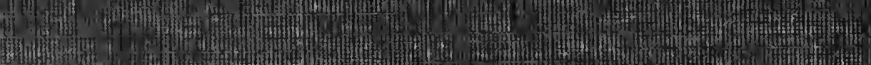
(1)

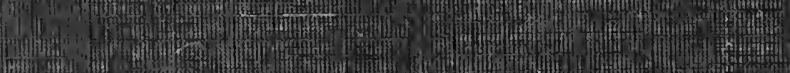

19.

17 (1)

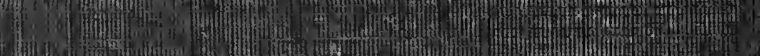

4.4.

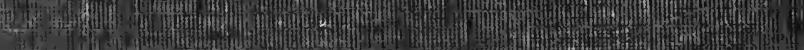

4.

(ning

a.t.

-

(3) (3)

(1)

(3) H. (m)

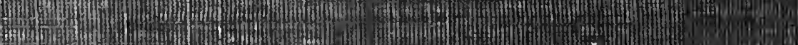

